\title{
THE BIRTH OF THE GODS AT PALENQUE
}

\author{
By David H. Kelley \\ University of Nebraska.
}

Heinrich Berlin (1963) has recently presented the interesting hypothesis that the Temples of the Cross, the Foliated Cross, and the Sun at Palenque are each associated with a particular deity and specified glyphs. He also suggested that these deities are somehow involved in lengthy cycles, not yet known. In studying these hypotheses, I found what I regard as substantial supporting data, and reached the further conclusion that the inscriptions refer to the birth of certain wellknown Mesoamerican deities, who can be identified by the glyphs pointed out by Berlin.

Subsequently, I learned that both of us had been partially anticipated by Seler (1901/2, pp. 17-19). Seler wrote "It is not inconceivable that with the Palenque altar-pieces the date inscribed at the top of the hieroglyphic series was merely intended to serve in a sense as the name of some particular deity, in whose honour this slab was carved, and in whose honour the temple was erected, in the cella of which the altarpiece was guarded. In fact, to me this seems to have been undoubtedly the case as regards the third of the altar-pieces, that of the so-called Sun Temple."

I know of no published attempt by Seler to extend this insight fully to the other temples. The suggestion that the date in the Temple of the Sun represents a calendar name for a deity was doubtless suggested in part by Seler's familiarity with codices which include the calendar names of gods. As Seler probably realized, but did not discuss here, the calendar names clearly refer to the date on which the deity was supposed to have been born.

It seems clear that, throughout Mesoamerica, there was a wide-spread concept that gors, like human beings, had been 
born and that dates could be assigned to their birth. Among the Aztecs, it was specifically stated that certain deities were born on dates which were also used as their calendar names. The Mixtec codices show some deities connected by umbilical cords to dates which function as their calendar names. These dates are more specific than the Aztec ones, since they are explicitly assigned to particular years of the 52-year cycle, and probably implicitly assigned to a specified date. All the deities shown in these Mixtec codices, probably including virtually all the deities in the Mixtec pantheon, have calendar names (see, especially, the Vienna codex).

The existence of calendar names for deities among the Mayas is strong evidence that the same concept existed in Maya culture in both Highlands and Lowlands. While few calendar names for specific deities have been preserved among the Mayas, there is considerable evidence that certain deities were known by the same calendar names throughout Mesoamerica. This means that comparative data may be utilized in explaining the nature of certain deities if reasonable care is used. Data for these generalizations may be found in Caso (1961) and in the material quoted subsequently.

Throughout the following discussion, I will use the common convention of giving calendar names of the deities in the English translation of the Aztec equivalent of the name. This makes for ease of comparison. The actual translation of some of the names would be different, but I hope this will not be misleading. I also follow Long (1926, p. 239) in the useful convention of writing, for example, "l Flower" for a date and "One Flower" for an individual. Since no such distinction is made in our sources, this may lead to some errors. However, when both dates and deitics are under discussion, I believe it helps to clarify the intent of particular statements.

The Initial Series in the Temple of the Sun is 1.18.5.3.6, 13 Cimi 19 Ceh. The Initial Series in the Temple of the Foliated Cross is 1.18.5.4.0, 1 Ahau 13 Mac, fourteen days later than the date in the Temple of the Sun. The Initial Series in the Temple of the Cross is much earlier at 12.19.13.4.0, 8 Ahau 18 Zec. After certain subsidiary dates, the count on the Tablet of the Temple of the Cross goes forward to 1.18.5.3.2, $9 \mathrm{Ik}$ 15 Ceh, only four days before the Initial Series of the Temple of the Sun. The chronological position of this date strongly 
suggests that it is closely parallel to the Initial Series of the Temples of the Sun and Foliated Cross, and should refer to the same class of events. This is verified by the external tablets of the three temples. Here the Temple of the Sun has $13 \mathrm{Cimi}$ 19 Ceh, the Temple of the Foliated Cross has 1 Ahau $13 \mathrm{Mac}$, and the Temple of the Cross has $9 \mathrm{Ik} 15 \mathrm{Ceh}$, all given as simple calendar round dates. The glyphs indicating the nature of the events which occurred on these dates are identical. The glyphs indicating the actor differ in the Temple of the Cross and the Temple of the Foliated Cross. Unfortunately, this section of the tablet of the Temple of the Sun is missing. It is these actor glyphs which Berlin (1963, pp. 92-3) identified as the probable names of the deities of the respective temples. The glyphs of the deity of the Temple of the Sun were identified from their association with those of the TC and the TFC.

We have two direct indications of the nature of the events referred to. First, one of the two 'event' glyphs of these panels is also found on a representation of a shell in the Temple of the Foliated Cross (fig. 1). The figure of a deity resembling god $\mathrm{K}$, holding a maize stalk with the head of the maize deity in it, is shown emerging from the shell. It seems quite possible that the event referred to is this emergence. While I know of no relevant Maya evidence, the commentator on the Codex Telleriano-Remensis (quoted in Seler, 1900/1, p. 58) writes "as the snail comes from its shell, so man from his mother's womb". As will be seen, this parallels other evidence suggesting that these tablets refer to the birth of the deities. If the lower glyph block on the shell refers to emergence from the shell, then its use on the exterior tablet of the Temple of the Foliated Cross must refer to the emergence of Berlin's god GII on the date 1 Ahau $13 \mathrm{Mac}$, its use on the exterior tablet of the Temple of the Cross must refer to the emergence of Berlin's god GI on the date $9 \mathrm{Ik} 15 \mathrm{Ceh}$, and its use on the exterior tablet of the Temple of the Sun must refer to the emergence of another deity on the date 13 Cimi 19 Ceh, presumably Berlin's god GIII, although we lack the direct evidence of the inscription.

The second direct indication of the nature of these events is also furnished by the Temple of the Foliated Cross. Proskouriakoff $(1963$, p. 155) has made the extremely important observation that the Maya frequently followed a distance number by a notation of the event from which it was counted. 

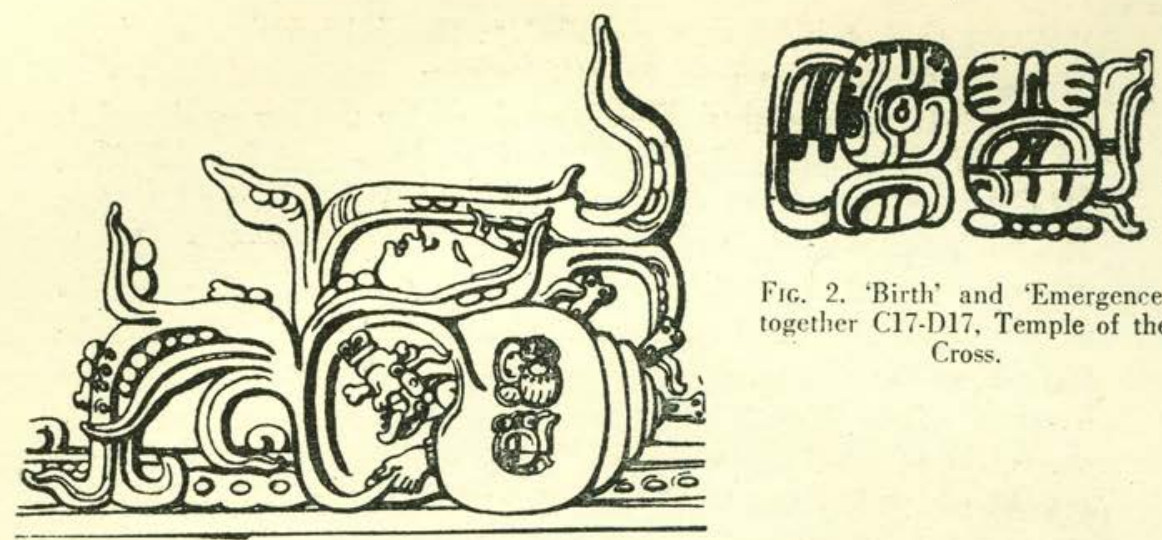

Fic. 2. 'Birth' and 'Emergence' together C17-D17, Temple of the Cross.

FIG. 1. Emergence of God K (variant) holding maize stalk with head of god E. Suggested "emergence" glyph group in lower glyph block on shell. Temple of the Folinted Cross.

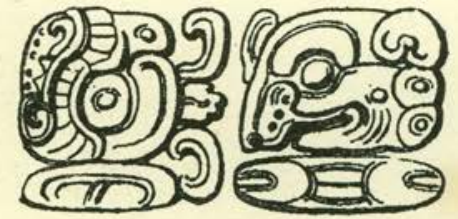

'birth"

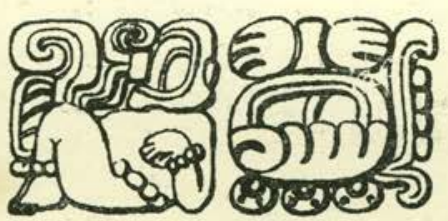

GII 'emergence'

Fig. 3. Palenque, TC.

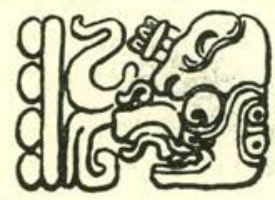

Fic. 4. Copan, Altar R; Glyph of God K with 'nine' prefixed, as deity name.

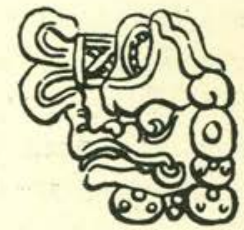

Copan, Stela J; Glyph of God K with verbal suffixes, as a verb. 
In the Temple of the Foliated Cross, a distance number counted from the Initial Series, 1.18.5.4.0 1 Ahau 13 Mac is followed by the 'up-ended frog' in C5 and by Berlin's glyphs for god GII in C6 (fig. 3, cf. fig. 2). Teeple (1930, p. 69) suggested that the 'up-ended frog' marked dates having the same lunar age. He presented no supporting data for this assertion, and I have been unable to find any. Thompson $(1950$, p. 48), based partly on the frequent use of this glyph in the lunar series, suggested the reading $p o$, 'frog, moon'. This may be correct, but is far from proven.

Proskouriakoff (1960, p. 460) has shown that the up-ended frog glyph with various affixes is normally associated in historical inscriptions with what she calls an initial date. She thought that such dates might be those of ceremonies following a birth, such as baptism. I have suggested that these dates are actually birth-dates (Kelley, 1962, p. 323). If my suggestion is correct, this passage constitutes a direct statement that Berlin's god GII was born on 1.18.5.4.0 1 Ahau 13 Mac. The immediately following glyph group is that which I have postulated as 'emergence'. It may be objected that this implies that two different glyph groups are used, alternately and together, to refer to birth. However, this is not implausible, as Munro Edmonson (personal communication) has drawn to my attention the common Mesoamerican practice of using paired words as couplets in formal or poetic discourse. As will be shown, the iconography of the tablets supports the view that 1 Ahau $13 \mathrm{Mac}$, $9 \mathrm{Ik} 15$ Ceh, and 13 Cimi 19 Ceh are actually birth-dates of deities.

The clearest iconographic evidence comes from the miscalled "Temple of the Sun". Here the date 13 Cimi would give a calendar name Thirteen Death. This name is known from Núñez de la Vega as that of "siete negritos" or of their chief, a cruel warrior, represented as a black god. Seler (1901, p. 94) quotes from Núñez de la Vega (Constituciones Diocesanas, n 32 , Roma, 1702) as follows: "En muchos pueblos de las provincias de este Obispado tienen pintados en sus repertorios o calendarios siete negritos para hacer divinaciones y pronósticos correspondientes a los siete días de la semana, comenzándola por el viernes a contar como por los siete planetas los gentiles, y al que llaman coslahun tox que es el demonio, según los indios dicen, con trece potestades, e tienen pintado en silla y con astas en la cabeza como de carnera." ..."tienen los Indios gran 

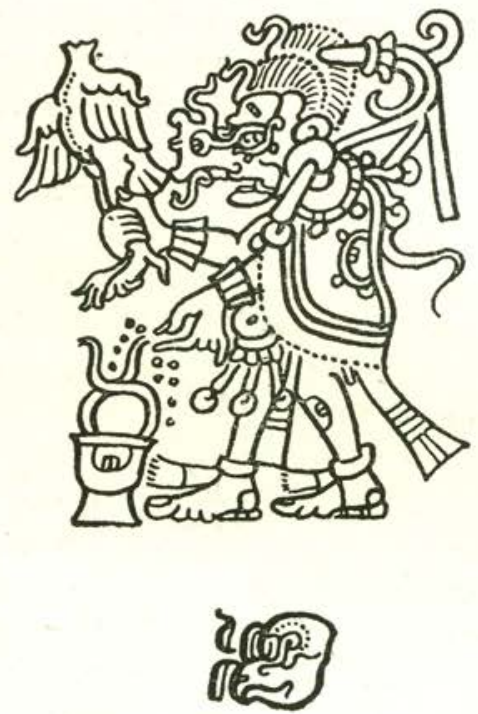

Fig. 5. God K, from the Dresden with his typical glyph, without 'nine' prefixed.
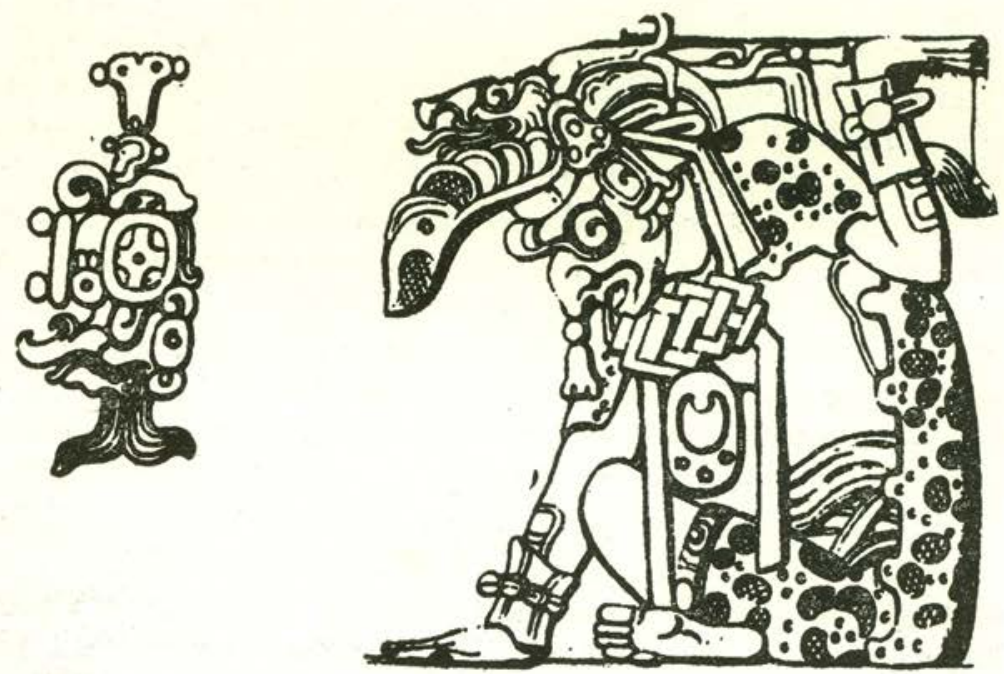

FIG. 6. Tablet, Temple of the Sun $a$. Seven-black-(deity): $b$. Note similarity of clothing to deity (FIG. 8) and headdress like God L and deity (FIG. 8). 
miedo al negro, porque les dura la memoria de uno de sus primitivos ascendientes de color Etiópico que fue gran guerreador y cruelísimo, según consta por un cuadernillo historial antiquissimo que en su idiom escrita para en nuestro poder. Los de Oschuc y de otros pueblos de los llanos veneran mucho al que llaman cYal ahau (verbessere Ycal ahau) que q.d. negro principal o Señor de negroes."

Seler drew from this the conclusion that the "siete negritos" actually formed part of the name of a war god in the form Uuc Ekel Ahau, "Lord of the Seven Blacks". The "coslahun tox" of this quotation, translated as "trece potestades", is actually the calendar name Thirteen Death, and seems to refer to the chief of the seven black deities, with whose name the count began on Friday. In support of his association of the 13 Death of the Initial Series of the Temple of the Sun with this name Thirteen Death, he pointed out a head with the glyphs for 'seven' and 'black' before it (fig. 6a), to the left of the central representation of the Temple of the Sun. Whether this refers to a single deity, the chief of the "Seven Blacks", or to all seven, the reference seems to me plausible.

The central design shows a shield and crossed spears (fig. 9). Elsewhere in Mesoamerica, these are regularly and appropriately used as symbols for war (fig. 10). The shield is supported by a serpent bar, supported in turn by two human figures. The figure on the left (fig. 6b) is the same as that represented on the panel ontside the sanctuary of the Temple of the Cross, the famous old man smoking (fig. 8). The headdress in both representations contains a bird and plumes and clearly identifies this figure with the black god $L$ of the codices (fig. 7). Seler (1902-23, iv. p. 636) clearly recognized this affinity but strangely seems to deny the distinction between gods $\mathrm{L}$ and $\mathrm{M}$. He apparently did not notice the identity of the figure outside the Temple of the Cross with the figure on the sanctuary tablet of the Temple of the Sun.

God $L^{\prime}$ is a rare figure in the codices and few of his attributes are certainly known. Representations of God L as originally defined by Schellhas (1904, pp. 34-5) are restricted to the Dresden. Thompson $(1950$, p. 76) separated a series of representations of a black god in Madrid. The deity in these representations is called god $\mathrm{Z}$ by Zimmerman (1956, p. 164) (fig. 13). Anders (1963, p. 363) has shown that this god 


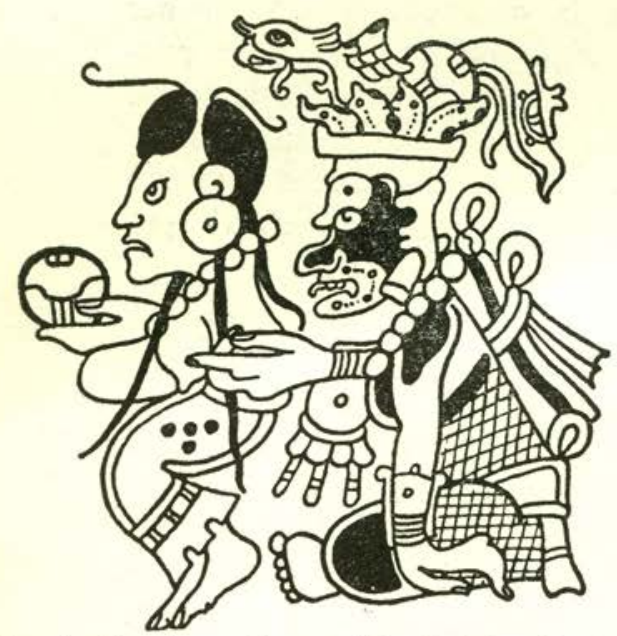

Fic. 7. Dresden codex, p. 14c God L, distinguished by fleshless lower jaw, white forehead. Note feathers (?), bird, and maize plant in headdress.

Fic. 8. Tablet outside sanctuary, Temple of the Cross, Palenque. Old man smoking. Note jaguar skin garment and jaguar ears. Headdress has feathers (?), mythical bird, and maize plant. In latter, note inverted head with death symbol.

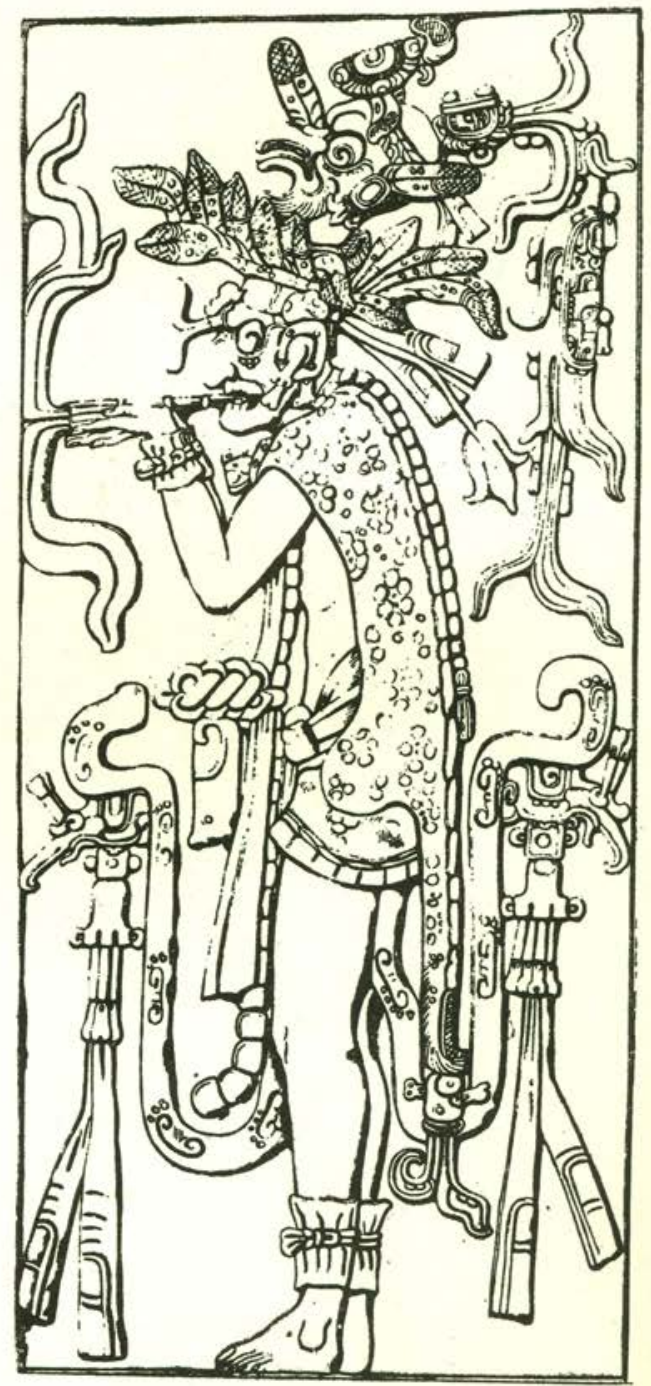




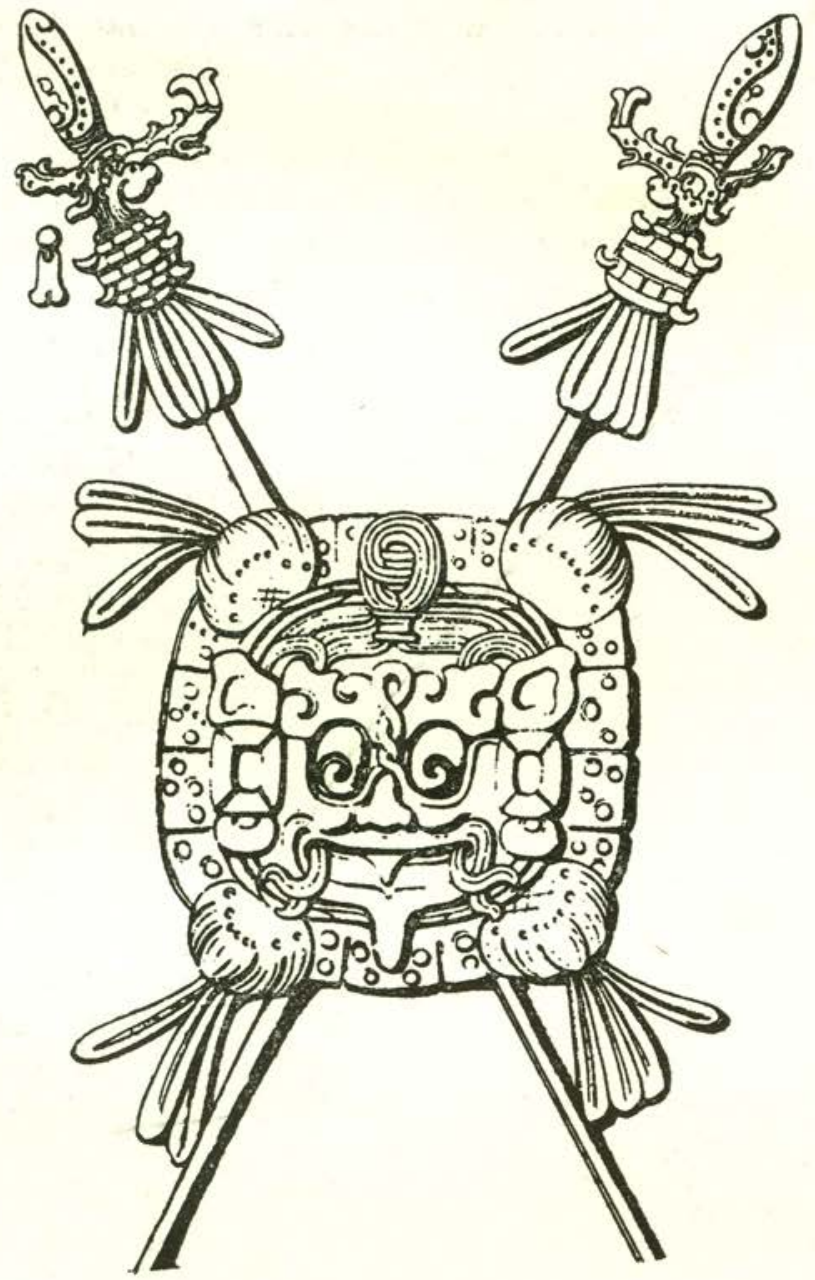

Fic. 9. Tablet, sanctuary, Temple of the Sun. Central shield and spears. Note humanized jaguar traits of face. 
appears in at least one scene (fig. 12) which is a close parallel to a representation of god L in Dresden (fig. 11) and suggests their identity, which seems to me highly likely. Representation with spear and shield suggest connections with war. As a black god associated with war, he is closely similar to god M. The following data indicate that god L corresponds to the Tzental deity Ical Ahau and to Aztec Mixcoatl, while god M corresponds to Ek Chuah of the Mayas and to Aztec Yacatecuhtli.

God M (fig. 17) is frequently represented with a merchant's bundle on his back and is also shown making, war on other deities. His most salient characteristic is a very long nose. The Aztec god of merchants is Yacatecuhtli, which means "Nose Lord" (cf. fig. 18). According to Sahagun (Relación breve ... 1948, p. 298), the birth of Tezcatlipoca and Yacatecuhtli occurred in Toxcatl. This corresponds to the Maya month Muan, in which Landa says there was a festival to Ek Chuah, god of merchants and cacao plantations (Landa, ed. Tozzer, 1941, p. 164). Ek is, of course, 'black' and the name may be related to Ek Chuh, a black scorpion (Brinton, 1895, p. 67, ff. Seler). Scorpions are frequently assoriated with representations of god M. Sahagun (op. cit., p. 303) also says that in the month Vey mica ihuiltl, the second month dedicated to the dead, Yacatecuhtli died and the merchants bathed people. This month corresponds to Maya Uo. The glyph of the patron deity for the month $U_{o}$ (fig. 15) is the head of the god of the number seven (fig. 16). This god has jaguar characteristics and a twisted design over his nose. He is apparently the deity represented on the shield in the centre of the design at the "Temple of the Sun". The twisted design is also found associated with both of the deities who support the shield. Thompson (1962, p. 282) points out that a recently discovered inscription shows the glyph of god $\mathrm{M}$ suhstituting as the patron of $U_{o}$, an identification I had previously made without knowing of this inscription (Kelley, 1962, pp. 29, 39). In the codices, the glyph of god M is like the eye of god L, with a white area above it. This furnishes a surprising cross-identification which emphasizes their relationship.

The Aztec Mixcoatl (fig. 20) is said to have introduced war (Codex Telleriano-Remensis, quoted in Thompson, 1934. p. 228) and among the Nicarao, Mixcoa was the god of merchants, emphasizing his similarity to Yacatecuhtli. Thompson 

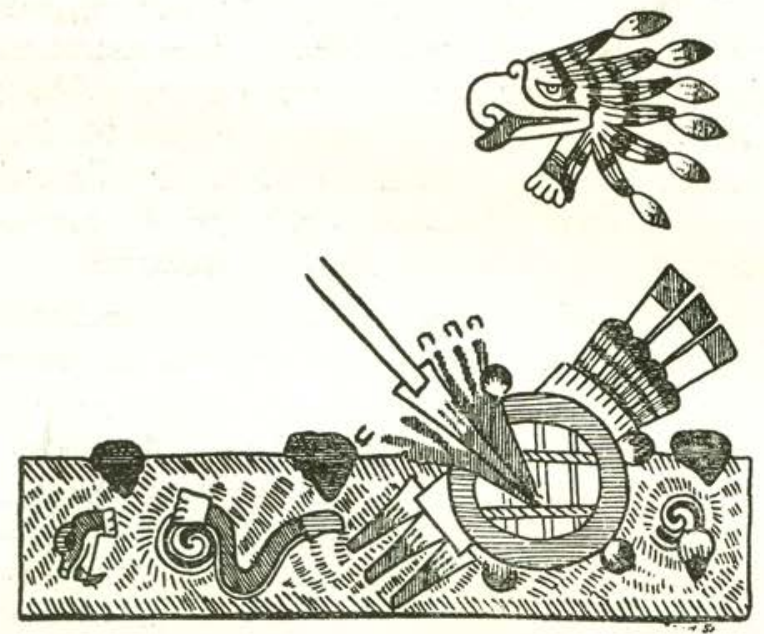

Fig. 10. Shield and spears from Borgia codex.

Fig. 11. Dresden codex, p. 74; Flood symbols, old death goddess and God L. Text includes 'black sky,' 'black earth.'

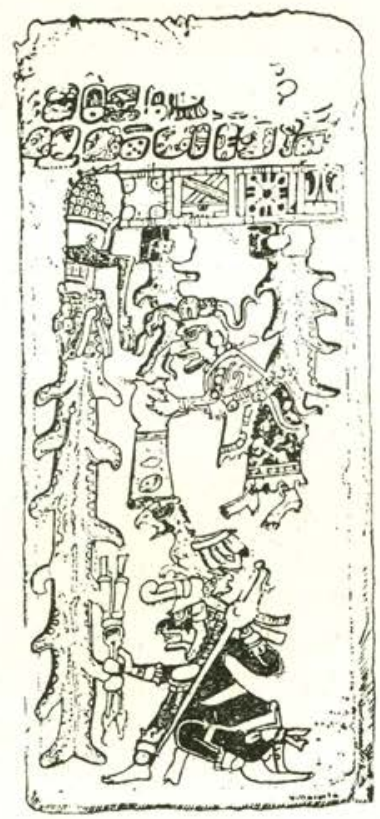


(1950, p. 76) attempted to identify god M with Mixcoatl, rather than with Ek Chuah as had been done by Cyrus Thomas, Seler, and others. I think the more traditional view is correct, but Thompson's attempt emphasizes once more the close relationships of these deities.

The deity figure supporting the shield on the right inside the Temple of the Sun (fig. 19) cannot be identified by me. If the twisted design over the nose indicates jaguar affiliations, as I suppose, he might be god M or possibly a Maya equivalent of Tepeyollotl. If the 'seven black' combination referers to god L, below, the glyph with 'nine' prefixed might refer to this deity. Seler (1901/2, p. 19) supposed that the 'nine' glyph here referred to the deity Ah Bolon Tzacab, but it seems to me that this does not agree either with the iconography or with his other evidence for the glyphs of Ah Bolon Tzacab, as will be shown.

Berlin's GIII glyph group, (fig. 14a), presumably for the deity of this temple, cannot be directly identified with any of the black gods by any evidence known to me, but the checkerboard shield suggests connections with war. The parallel passages in the Temple of the Jnscriptions, cited by Berlin, have, in passage $3 \mathrm{a}$., for a glyph which should, from the context, be a substitute for GIII (fig. 14b), either as another glyph for the same deity or, less probably, as another deity. It has a glyph on the forehead which I think is 'black' and the treatment of the eye and mouth closely resemble that of the head of 'seven'. This offers some support for the identification of GIII as Ical Ahau.

In the inscription of the tablet of the Temple of the Sun, the "up-ended frog" glyph, which I think is 'birth' appears at $\mathrm{Cl}$, followed by a long passage which includes a "half-darkened ahau" at D1, a headless jaguar at D2, the glyph group for "fire" at C5 and finally GIII at D6. Both headless jaguar and the reference to 'fire' seem appropriate to a war god. I think that this passage refers to the Initial Series, despite an interpolated passage, since a similar interpolation occurs both in the Temple of the Cross and in the Temple of the Foliated Cross. I also think that GIII is the subject of the sentence beginning with the 'birth' glyph, despite the number of intervening glyphs. 
FIg. 12. Madrid codex, p. 32a; God Z, with shield and spears. Note fleshless lower jaw, white area over eye. Associated with flood and night symbols. Bottom half of page shows old death goddess.

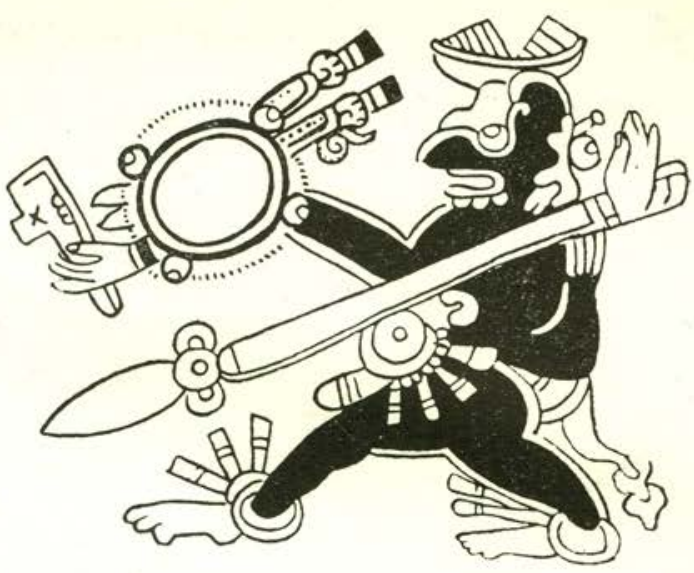

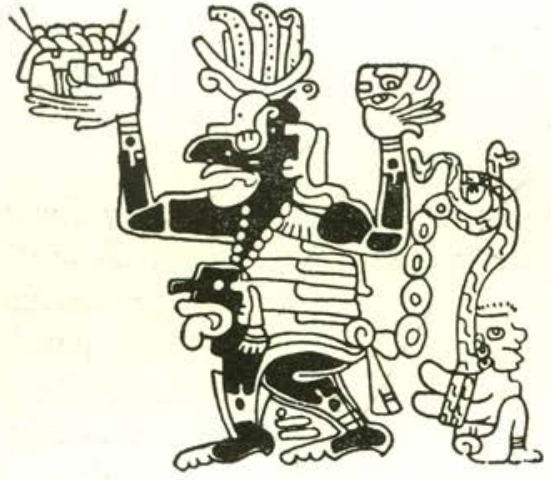

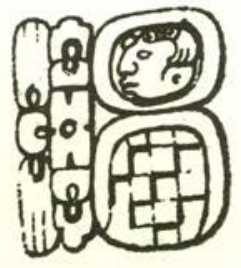

FIG. 14a. Glyph group of GIII.

Fic. 14b. Glyph group substituting for GIII, Temple of the Inscriptions.
FIG. 13. Madrid codex p. 33b. God Z with head of God M at waist.
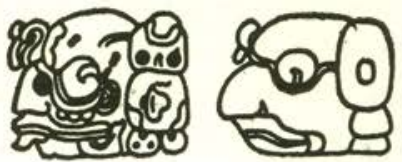

Fig. 15. Glyphs for the patron deity of the month Uo.
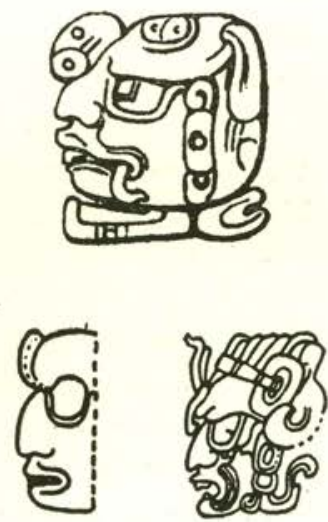

FIG. 16. Glyphs for the number seven. 
In sum, the "Temple of the Sun" seems to show the shield and spears as a symbol of war, supported by two deities, one of whom is god L, a black god of war. The "seven-black-x" glyphs above him correspond with references to a Tzeltal deity, who led seven black gods, who was called a warrior, and who was also called Thirteen Death. $13 \mathrm{Cimi}$, which corresponds to 13 Death, is the Initial Series of this temple. 'Birth' glyphs are found in the inscription, possibly referring to the birth of Berlin's god GIII on this date, although the evidence is not entirely clear.

The iconography of the Temple of the Foliated Cross is not quite as obvious, but all the evidence taken together seems fairly clear. The centre of attention is a stylized maize plant, treated as a tree, with a quetzal perched on it. The quetzal has a deity head. At the foot of the tree is the head of a deity with a kan cross marked on his forehead. The tree is decorated with heads of the maize god and of a god with a flare in his forehead, like god $\mathrm{K}$, but apparently differing from him in the nose. He may be a variant of god K. Berlin's "glyph GII", which he regards as probably the name of the patron deity of this temple, is that of a god with a flare in his forehead, identified by Seler as god $\mathrm{K}$ and as Ah Bolon Tzacab (figs. 2, 4, 5). Berlin questions this identification of this glyph group because of the wide varation in affixes in different contexts. While accepting this as a generally valid reason for doubt, I think that subsequent data shows that some of the marked variation in glyphic affixes is partly paralleled by variation in names in our sources. Seler (1887, in 1902/23, I, 377-8) originally identified god K of the codices with Ah Bolon Tzacab because god $\mathrm{K}$ was the regent of the ben years in Dresden and Landa gives Bolon Zacab as regent of the corresponding kan years. In the codices, the glyph of god K (Z 742) never has the prefix 'nine', while Landa and the books of Chilam Balam, in the supposed parallel passages, do have 'nine' (bolon) prefixed. The glyph Z742 is found frequently, with 'nine' prefixed at Copan, and rarely elsewhere. It is clear that Z742 appears in some contexts merely as a word (fig. 4b), but in other contexts, with or without 'nine' prefixed, as a deity name. Hence, in cases where the context indicates that a deity is referred to, I am inclined to think the reference is either to a single deity or to a series of very closely related deities. Thompson (1934, pp. 226-7) accepts the identification 

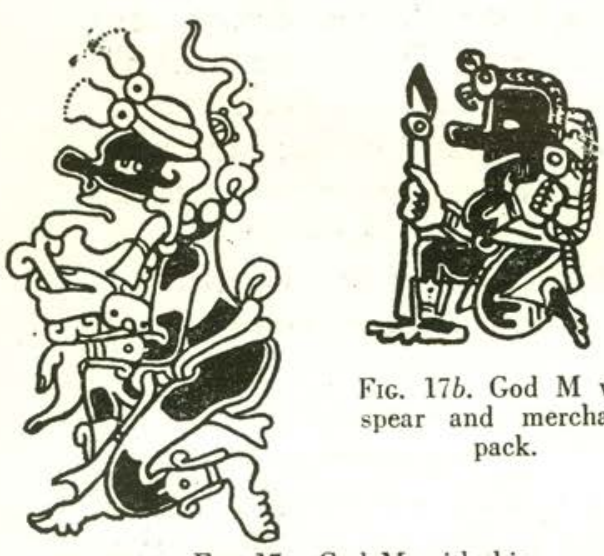

FIG. 17b. God M with spear and merchant's pack.

FIG. 17a. God M with his ลิ typical hieroglyph - probably Ek Chuah.

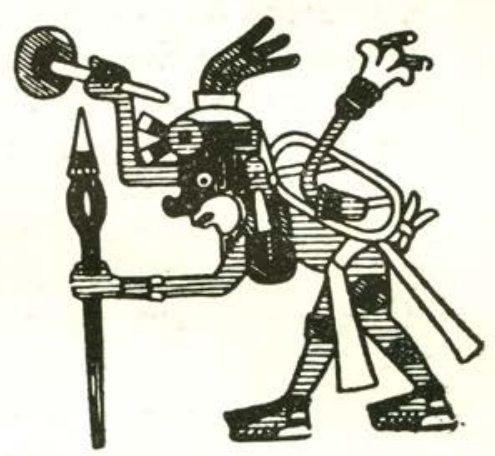

Fic. 18. A merchant god from Fejervary-Mayer, probably an equivalent of Yacatecuhtli - compare nose with God M.

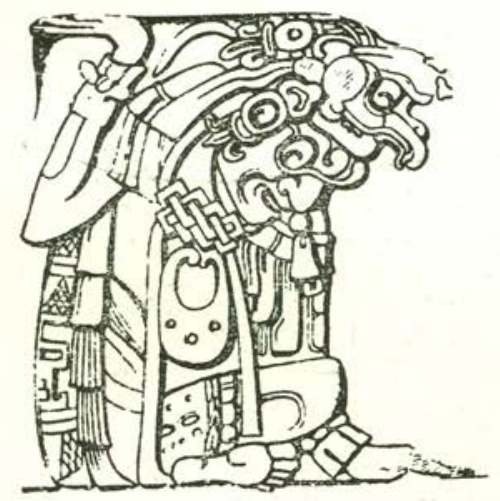

Fic. 19. Palenque. TS Deity from right side of tablet with glyphs which may give his name.
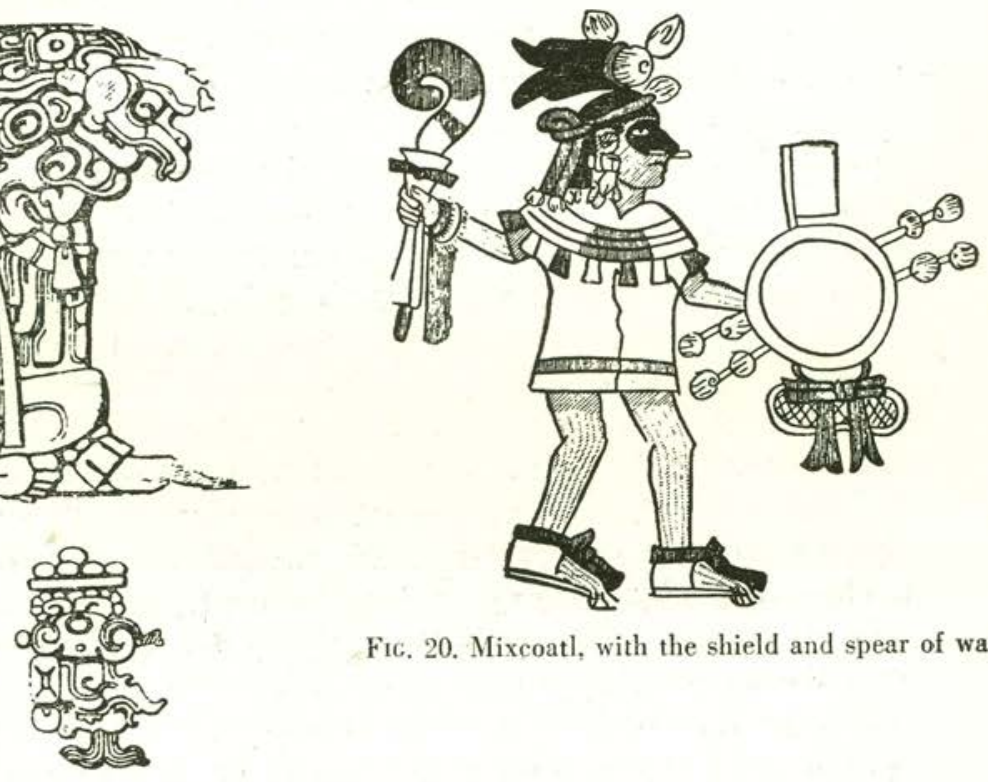

Fic. 20. Mixcoatl, with the shield and spear of war. 
of Ah Bolon Tzacab with god K, calls him an agricultural god and equates him with the Mexican Centeotl, god of maize. His reasons are the similar associations of the two deities with the east, and the overlap in their functions. Seler (1904, p. 376) shows a similar overlap of functions with Chalchiuhtlicue. Neither equation implies an identity and both may be partly valid. According to Serna (quoted by Caso, 1961, p. 95) the calendrical name of Centeotl was One Flower. According to Sahagun (Caso, loc. cit), Centeotl was born on the day 1 Flower in Tamoanchan. The name Tamoanchan is apparently Mayan and may suggest borrowing of associated religious concepts from the Mayas. The Initial Series of the Temple of the Foliated Cross is 1.18.5.4.0 1 Ahau 13 Mac. 1 Ahau is, of course, the equivalent of the Mexican 1 Flower. The 'upended frog', which I believe indicates birth, is at B16 with a series of obscure glyphs in A17-C2 and the glyph GII for the god in D2. One would normally think this was associated with the date directly preceding (1.18.6.0.19 1 Cauac 7 Yax) but a phrase intervenes and the subsequent secondary series is counted from the Initial Series. Between the secondary series and the date it reaches (2.0.0.0.0, 2 Ahau 3 Uayeb) appears the 'birth' glyph again in C5 and GII in C6. As previously mentioned, this indicates clearly that Berlin's god GII was supposed to have been born on 1 Ahau (1 Flower). The fact that a god with a flare in his forehead is shown emerging from the snail shell with a maize god and that the associated glyph suggests that this is what god GII was supposed to have done indicates in this context that glyph GII should refer to this variant of god $\mathrm{K}$ or to the maize god. It is worth noting that a stylized One Ahau appears directly associated with the head of the maize god in the tree (fig. 21).

Seler (1902/3, pp. 132-3, 164/5 and elsewhere) has argued that Centeotl, despite his specific function as Maize god, is actually a more general god of vegetation and even generic ruler of food supplies and affluence. He points out an implicit identification with Xochipilli (Flower Prince) and shows a substantial overlap in their calendrical roles and iconography, although it is usually possible to distinguish them. Xochipilli seems to have a similar overlap with the sun god, and Seler also argues that at some level of Aztec mythology he was 

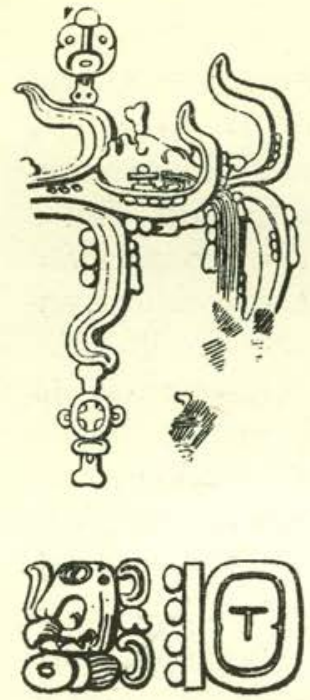

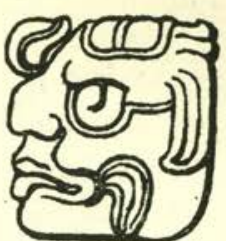

Fic. 22. Glyph of GI.

FIG. 21. Temple of Foliated Cross, head of maize god (E) with stylized One (?)

Ahau above the head.
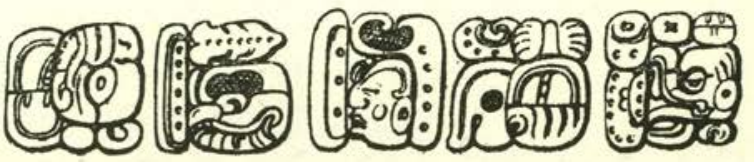

FIG. 23. Temple of the Cross xoc-ti-?

count feather?

(back) to 9 Wind 'birth' snake

E12

E13 F13

'emergence'
?

Palenque Emblem

Glyph

E14 F14 E15

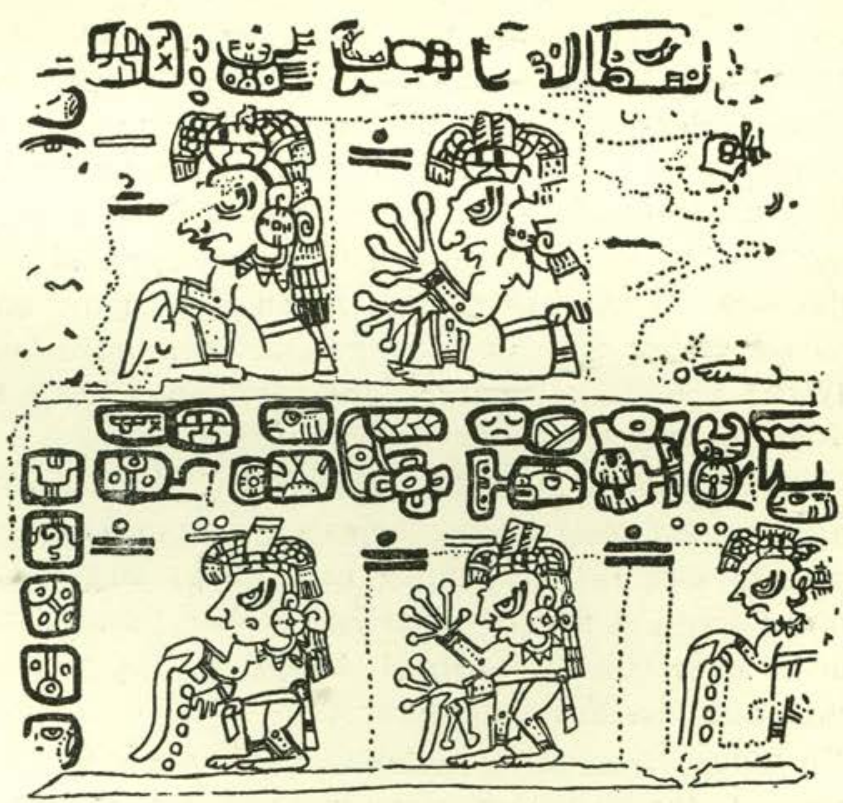

FIg. 24. God P from the Madrid. Note that the strange 'hand' is apparently detachable, and surely has nothing to do with a tree toad's foot. 
equatable with Tonacatecuhtli, lord of subsistence, and god of procreation.

In the Vienna codex (p. 23) a double sun-dísk is shown, with the sun god seated in the upper disk and the day-sign 1 Flower in the lower disk. Here One Flower is apparently a name of the sun god, overlapping thus with Centeotl and, inferentially, with Xochipilli.

Other Mesoamerican deities named One Flower may be related in some fashion to those previously mentioned, either through differentiation from a common origin, or through assimilation of traits of originally differentiated deities. The material should also be pointed out as providing possible alternate interpretations to the identification of One Flower at Palenque. The Quiche culture heroes, Hun Hunahpu (One Flower) and Vukub Hunahpu (Seven Flower) were brothers who descended to the land of the lords of death. Defeated in a ball game and in various tests by the lords of death, they were killed. The head of One Flower was cut off and became a gourd in a gourd tree (Popul Vuh, Recinos, Goetz and Morley, pp. 107-120) in which form he magically impregnated the daughter of Cuchumaqiq and became the father of twins named Hunahpu and Xbalanque. Later, these twins are said to have caused Hun Hunahpu and Vukub Hunahpu to become the sun and the moon. Since both One Flower and Seven Flower are known elsewhere as names for a sun god, we cannot determine which of them is here the sun god and which the moon god.

The Maya Hun Ahau (One Flower) is said by Landa to be the ruler of the underworld. As such, he may have been the 'Night sun' or sun as a death god in the underworld. Thompson (1950, pp. 218-219) argues that Hun Ahau was a name of the Venus god (or of a Venus god). Direct evidence is not extensive. Possibly relevant is the fact that 1 Ahau 13 Mac, here the Initial Series, appears as a calendar round date in the Dresden as one possible base for the Venus cycle. It is by no means impossible that a single deity may have been conceptualized as filling all of these functionally distinct roles, but at present they seem to involve quite different concepts.

We may sum up by saying that here the Initial Series clearly refers to the birth of Berlin's god GII, that the glyphs for GII have long been regarded as referring to god $\mathrm{K}$, also identified 

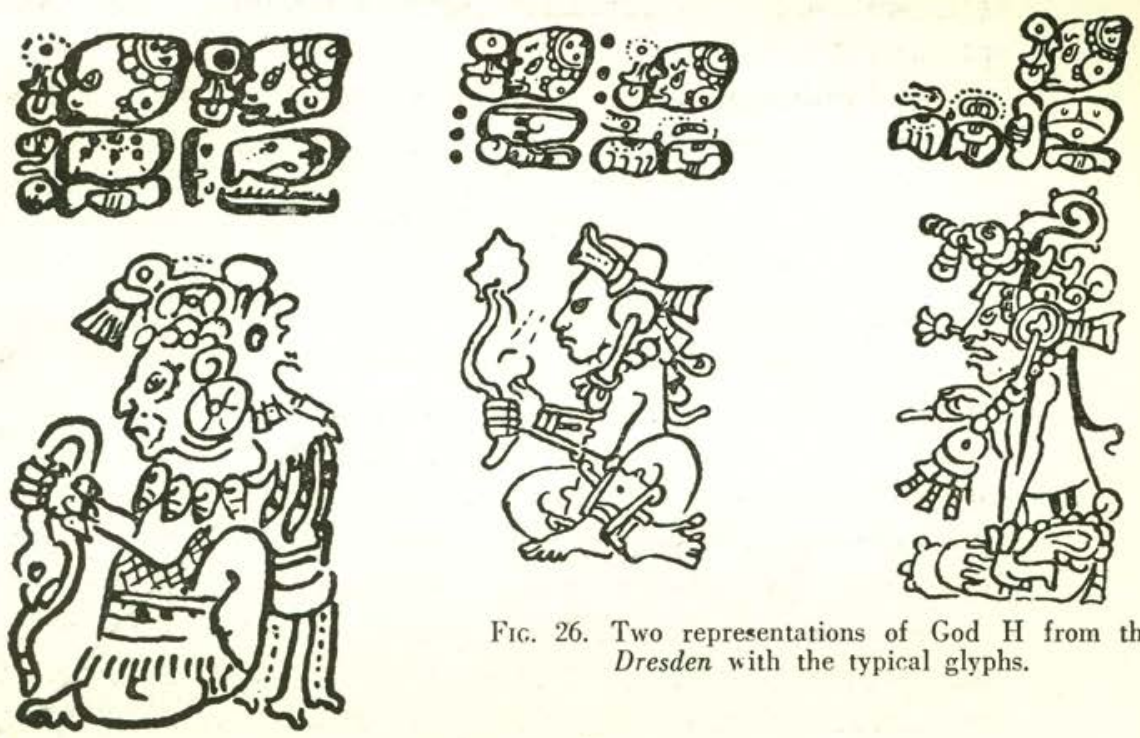

FIc. 26. Two representations of God $\mathrm{H}$ from the Dresden with the typical glyphs.

FIG. 25. God P from the Dresden. Note serpent staff in hand, apparent quetzal bird on back, glyphs of God $\mathrm{H}$ above; cf. figs. 39-41.
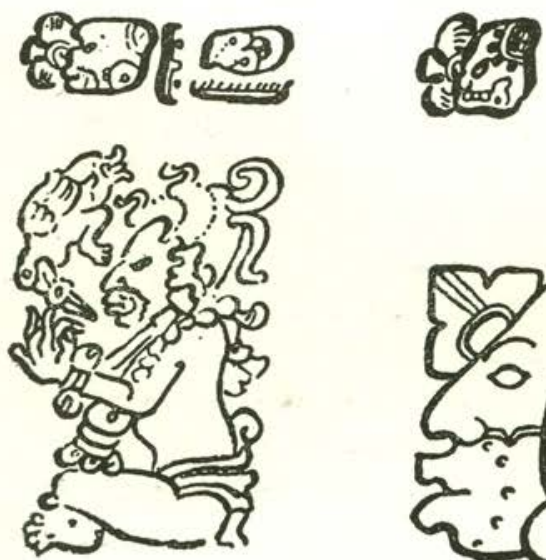

FiG. 27. Representation of God $\mathrm{CH}$; note yax prefix to name.
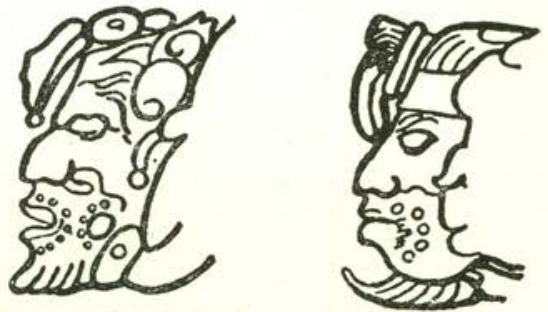

Fic. 29. Two bearded heads of the god of number nine from the monuments.

Fic. 28. Glyphs of God CH from Dresden compared with head of god of number nine from the monuments, both with yax prefix. 
as Ah Bolon Tzacab, and that god K was apparently a god of agriculture. The iconography of the tablet seems to show various forms of god K and of the god of maize. The date of birth, 1 Ahau, corresponds to the day 1 Flower, which was said to be the birthdate of the maize god, Centeotl, who was partially identified in native thought with the sun god. A partial overlap of functions between Ah Bolon Tzacab and Centeotl had been suggested previously.

For the Temple of the Cross, the iconography is not so clear cut and I believe that the Initial Series and earlier dates are prefatory not only to the Temple of the Cross, but also to the Initial Series of the Temples of the "Sun" and Foliated Cross. The opening Initial Series is 12.19.13.4.0 8 Ahau $18 \mathrm{Zec}$, prior even to the beginning of the Maya era. A count back of twenty days is then given to 12.19.13.3.0 1 Ahau 18 Zotz, a base in the 819-day count, which is immediately followed by the 'birth' glyph, which is in turn followed by the apparent glyph of the earth goddess with a prefix (T 69). Judging by other examples of the use of the 819-day count, the clause should refer back to the opening date, 8 Ahau $8 \mathrm{Zec}$, which, in terms of the present hypothesis, should be a calendar name, Eight Flower, probably for the earth goddess. A count then goes forward to the normal Maya era 4 Ahau 8 Cumku (13.0.0.0.0) and thence to 13.0.1.9.2, $13 \mathrm{Ik}$ end of Mol. From this date, the count goes forward 1.18.3.12.0 to the date 1.18.5.3.2, 9 Ik 15 Ceh. The tablet outside shows this calendar round date as the time at which something happened to Berlin's god GI (fig. 22) which was comparable to what happened to Berlin's GII on 1 Ahau 13 Mac. Since I think there is good evidence that the latter was supposed to be his birth, it seems likely that this date was also the birth of a god. This would mean that GI's calendar name was Nine Wind. Analyzing the material is complicated by references to other dates 9 Wind in this inscription.

At a date which is not clear to me, we find 9 Wind in F12 and 'birth' with unusual affixes in E13. This passage, E12-E15 (fig. 23) seems to refer back to the birth of an important deity whose glyphs appear in F13. In F13 we have T 11.212:764 (figs. 23, 53). Glyph T764 is the glyph which also appears as the name of the day corresponding to Yucatec Chicchan. Since I hold as a working premise that it is unlikely 

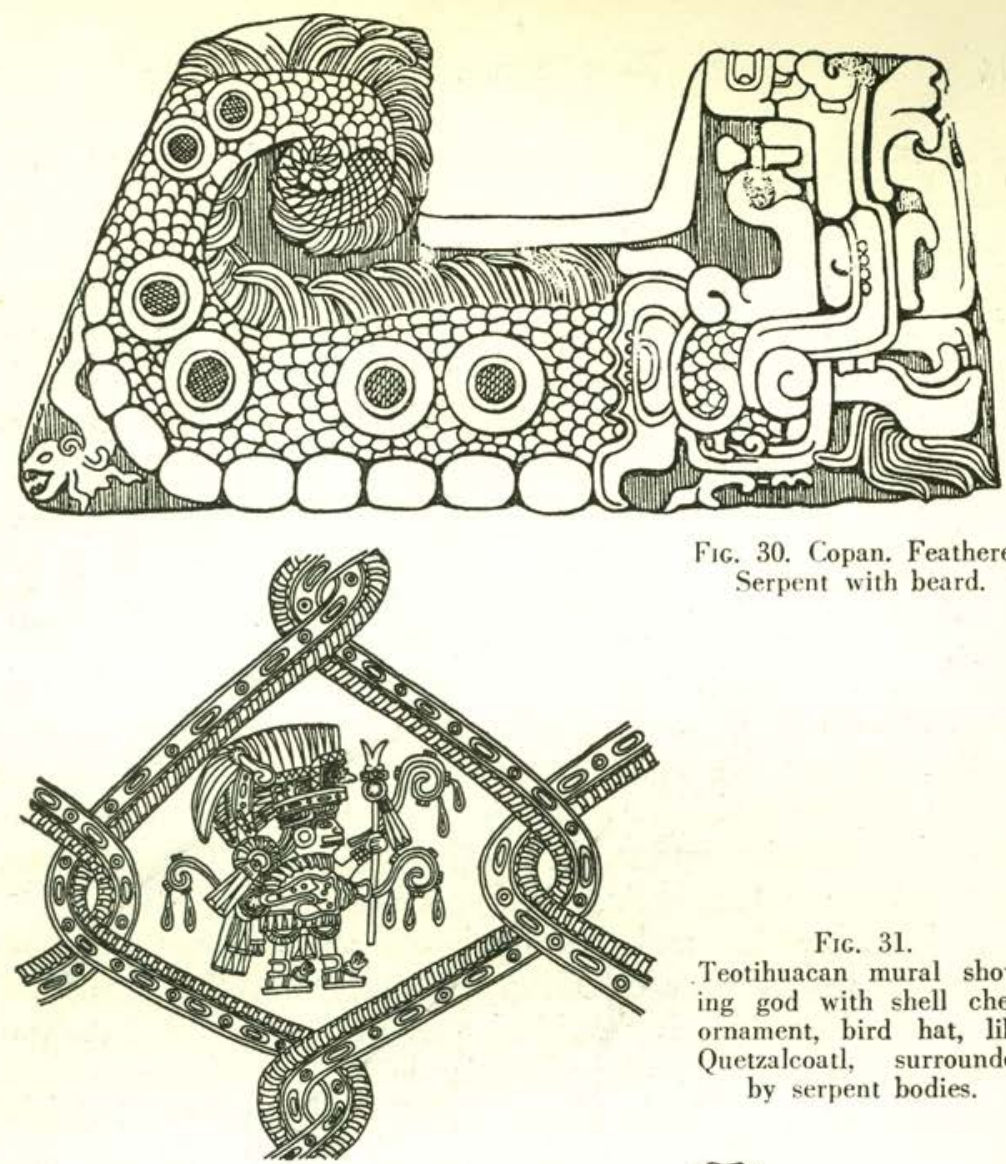
FIG. 30. Copan. Feathered Serpent with beard.

FIG. 31.

Teotihuacan mural showing god with shell chest ornament, bird hat, like Quetzalcoatl, surrounded by serpent bodies.

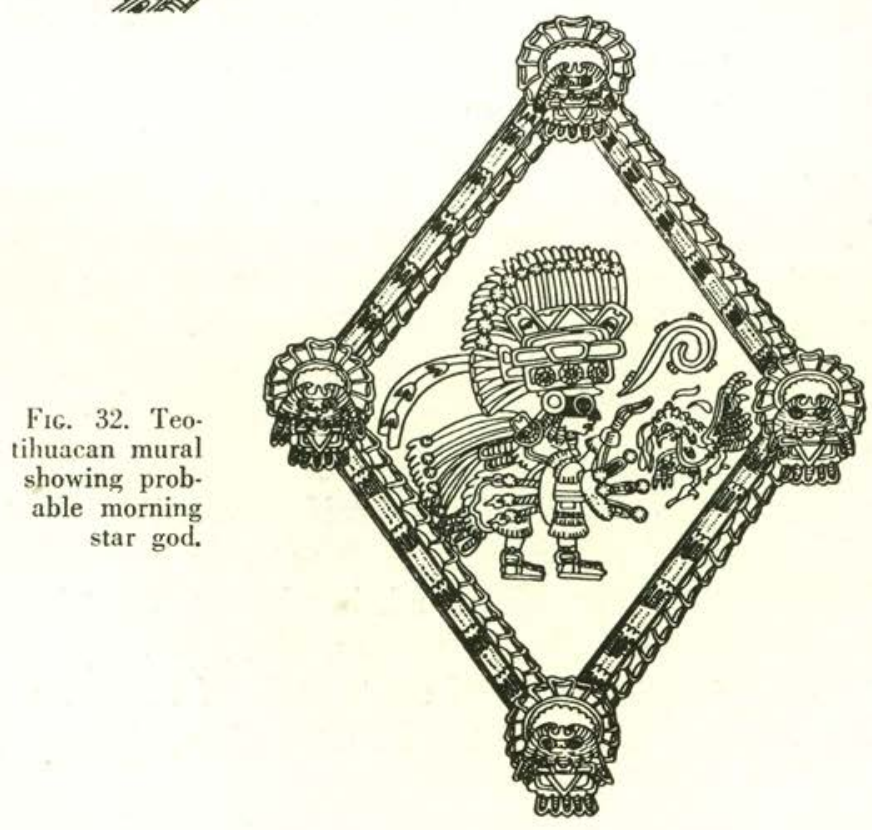


that a single glyph in Classic times represented two morphemes, I think T764 is probably the glyph for can, 'snake'. T11 is normally a grammatical affix, but could be phonetic here. Thompson's glyph 212 is clearly the same as the central element of the rear head of the two-headed dragon (figs. 49, 50, 51), described by Seler (1902-23, III, p. 723) as "like a feather". If it is actually to be read 'feather', Maya $k u k$, then we have here the name Kuk can, Feather Snake, the prototype of later Kukulcan. The appearance of $\mathrm{T} 212$ as a reptile tooth in the headdress of the deity on the left outside the Temple of the Cross (fig. 52) is puzzling by any interpretation. Since the heads of the maize god and of a god with a flare in his forehead which appear on the tree of the Temple of the Foliated Cross seem to be central to the iconography of that temple, it may be that the serpents which appear on the tree of the Temple of the Cross play a similar role in indicating that a serpent deity was of central importance in the Temple of the Cross. It may be pointed out that Kukulcan/Quetzalcoatl is usually said to have been bearded and that feathered serpents are often represented with beards on Maya monuments, at Palenque and elsewhere (fig. 30 ). It should also be pointed out that the god of number 9 shows strong affinities with the Chicchan serpent and with the yax glyph (figs. 27, 28) (Thompson, 1950, p. 75 ). In the light of this, it seems significant that the most striking characteristic of the god of number 9 is his beard (fig. 29).

The dates 9 Ik 15 Ceh, 13 Cimi 19 Ceh, and 1 Ahau 13 Mac, all fall in a katun 4. Ahau. The prophecies for katun 4. Ahau in the books of Chilam Balam throw considerable light on the inscriptions of these tablets. It is said that at this time the quetzal will be on the kaxte tree or the Hoben tree. I believe that kax may appear mistakenly for kaax, 'harvest'. One of the names of the Yucatec maize god was Yum Kaax, 'Lord of Harvest' and kaax-te, 'harvest tree', would be an appropriate name for the Foliated Cross itself, with all its representations of maize and the maize god. The other name, Hoben, is ' 5 Reed', a day name. Whether it is relevant or not I am not sure, but the glyphs for ' 5 Ben' appear, with a prefix to Ben, directly to the right of the tree of the Temple of the Cross, and to the left in the Temple of the Foliated Cross. In the Temple of 
the Cross, this glyph block is directly above a glyph block consisting of $h o$, a deity head, and the affix $t e$, possible here 'tree'. The latter is also repeated in the Temple of the Foliated Cross, considerably removed from the first. Berlin (1959, p. 8) has suggested that these two glyph blocks go with the tall priest, and that another pair of ho-?-etz'nab (5 Flint) and ho-tu-kal go with the smaller figure in these scenes. The distribution of the glyph blocks in the Temple of the Foliated Cross, widely separated from each other, makes it seem unlikely io me that two glyph blocks go with each figure, although one easily may. Whatever the relevance or irrelevance of the ho-ben tree, the reference to quetzals on the kax-te seems to me to correspond to these scenes, since quetzals are represented perched in both trees.

Returning to the prophecy, it is said that the morning star will appear (possibly a reference to One Flower or, as will be seen, to Nine Wind), that there will be blood vomit and sudden death, a probable reference to Thirteen Death, and that Kukulcan will come with the Itzas (Roys, 1933, pp. 133, 161; Barrera Vásquez and S. Rendón 1948, pp. 118-9, 140-1). As will be seen, the latter makes a very plausible reference to Nine Wind.

Since there are several dates 9 Wind in the tablet of the Temple of the Cross, we may have several conceptually related gods named Nine Wind, as seems to have been the case among the Mixtecs. Throughout the rest of Mesoamerica, Nine Wind seems to appear as a calendar name of Quetzalcoatl as wind god, Venus god, and claimed progenitor of royal dynasties. According to the Telleriano-Remensis (quoted by Caso, 1961, p. 82), 9 Wind was the day on which Quetzalcoatl was born. The Vienna codex (p. 49) shows the birth of Quetzalcoatl, with a flint knife for a mother, on the day 9 Wind of the year 10 House (fig. 42).

The identity of Nine Wind with the late Quetzalcoatl, and hence, probably, with the equivalent Kukulcan is well established. However, the fact that no recent Maya scholar has believed that Kukulcan was of any importance until the Toltec period shows the necessity for a re-examination of the evidence. Although I cannot agree with many of her conclusions as to the nature of Mesoamerican religious beliefs, Séjourné (1960, 
1962) has clearly shown that a series of concepts later associated with Quetzalcoatl are already found in probable association with each other during Teotihuacan III times. She has shown the presence of the concept of the bearded human called 'Feathered Serpent' as ruler (fig. 34), the cut shell symbol, the association with feathered serpents (fig. 31), the cult of the morning star (fig. 32) and the reference to his monstrous twin, Xolotl (fig. 33).

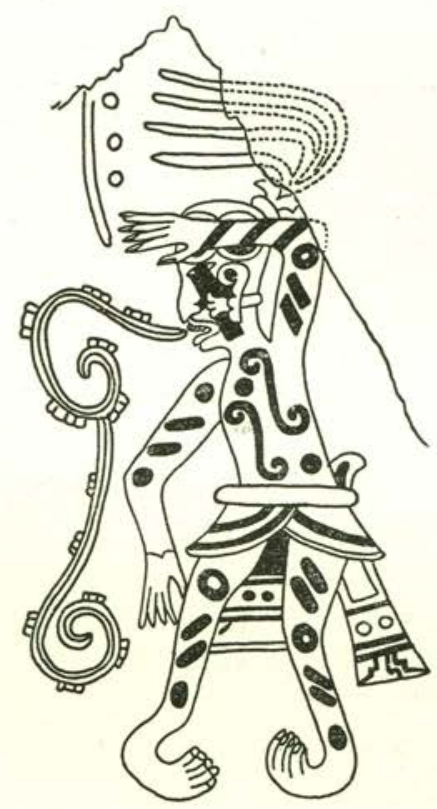

Fic. 33. Teotihuacan mural showing god with characteristics of Xolotl, twin of Quetzalcoatl.

In the famous inscriptions at Xochicalco, a representation of a feathered serpent surrounds an individual and a date, '9 Reptile-eye' (fig. 35). Caso (1959, pp. 55-60) has argued that 'Nine Reptile-eye' is the calendar name of the individual shown, who was also called 'Feathered Serpent', and that 9 Reptile-eye is the equivalent of 9 Wind in other Mesoamerican calendars. The apparent date of this material is late Classic.

In the Cotzumahualpan region of Guatemala, recent work by the Milwaukee Public Museum, under the field direction 
of Lee Parsons, has shown that the fully developed Cotzumahualpan style belongs largely to the late Classic. Cottie Burland (1958) has recently drawn attention to Stela 1, El Castillo, near Cotzumahualpa. According to Parsons (personal communication), this monument is typical of the Late Classic form

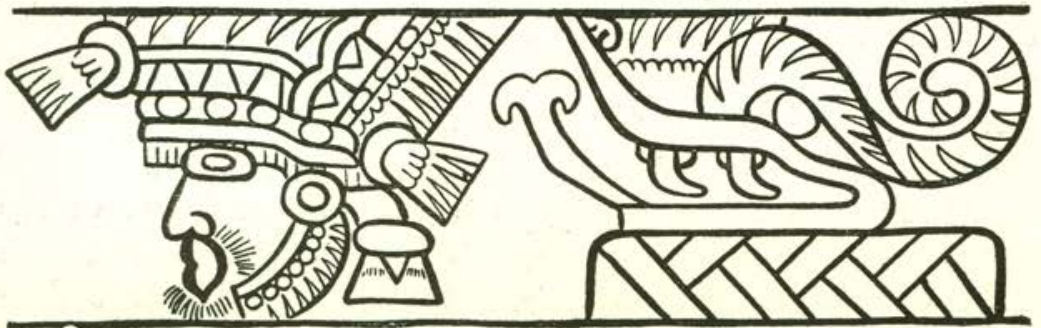

Fig. 34. Teotihuacan vase 'Feathered Snake' as name above mat to indicate royalty with representation of bearded human.

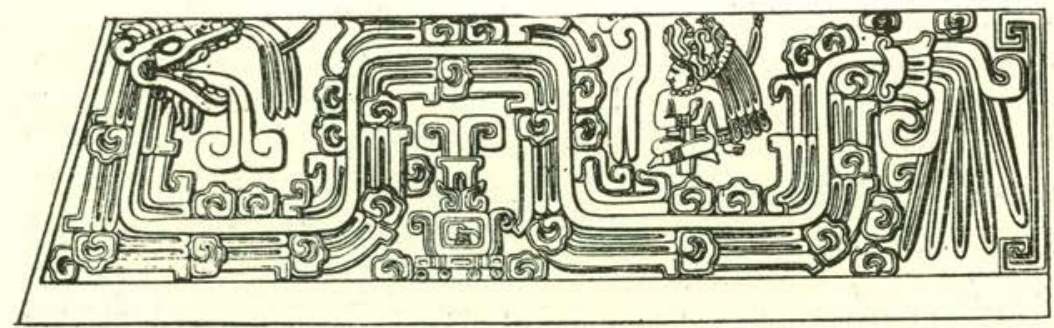

FIG. 35. Xochicalco. Feathered Serpent with human figure and name (?) Nine Reptile Eye. 
of Cotzumahualpan. Burland claims that the climbing figure shown on this monument is a representation of Xiuhtecuhtli and interprets the accompanying glyphs as dates of the Venus cycle (fig. 36). From the available data, he suggests the date 24 November 416 A.D. for the phenomena represented. While some of his basic material is mistaken, as will be seen, I think his central identification of the monument as a representation of Venus phases is correct. The climbing figure wears a headdress which corresponds to the representations of the day signs in the lower left of the inscription. Burland interprets these as referring to the day Crocodile. A recent comparative study by Parsons (Ms., 1964, p. 82) demonstrated clearly that these are actually reptile eyes. although differently formed than those of Xochiacalco. The climbing figure is accompanied by nine large dots, regularly shaped. A tenth, irregularly shaped dot, with apparent internal markings, is, I think, irrelevant here. The published drawing of Burland omits one plain dot which is clearly present in photographs kindly supplied by the Milwaukee Museum. I regard the headdress and nine dots together as forming the name of the climbing figure, "Nine Reptile-eye". This figure is certainly of the sort which in the codices normally refers to astronomical phenomena. The fact that Nine Reptile-eye is an astronomical figure here and is associated with the Feathered Serpent at Xochicalco is strong support for Caso's identification as Nine Wind. This means that the day-sign must be read as Wind instead of Crocodile and eliminates the mathematical basis for Burland's calculations. It may also be pointed out that the glyphs read by Burland as 5 Eagle actually consist of two 'crab' glyphs and 3 examples of another glyph, which I consider still unidentified. The day 'crab' is, unfortunately, not known in other Mesoamerican calendars and hence re-working of the mathematical basis of the inscription may prove difficult.

Finally, both the Borgia group codices and the Mixtec codices show the fully developed identification of Feathered Serpent, Wind god, and Venus god. The Borgia shows a bearded Quetzalcoatl wearing the cut shell and the mask of the wind god, (fig. 40). Elsewhere in the same codex, he is shown on a throne (fig. 41) or supporting the starry heavens, as he does in the Vienna (fig, 39). He reappears regularly in the Vienna with the calendar name Nine Wind, and once with a figure of a 


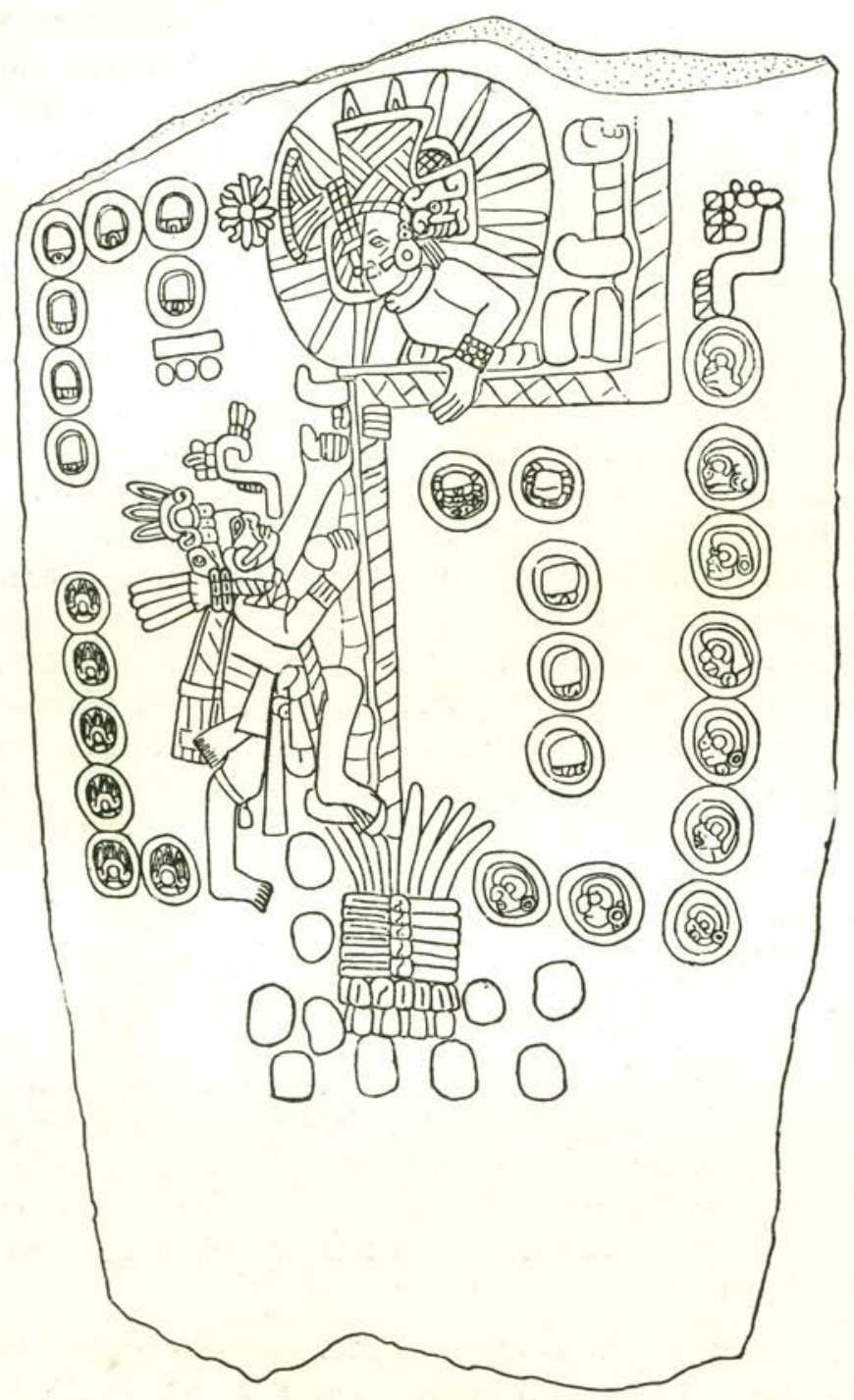

FIG. 36. El Castillo, Stela 1. Climbing figure of Nine Reptile Eye. 
feathered serpent with apparent canine characteristics, which, in this context, should represent his name (fig. 37). Sometimes he carries the socalled 'Venus staff' which resembles the Maya 'star' glyph, as on page 48, where he descends from heaven on a day 5 Reed of a year 6 Rabbit (fig. 38). He appears with One Flower as a dynastic progenitor in the Vienna (fig. 43). For comparison, I include also some representations of the Maya gods $\mathrm{P}$ and $\mathrm{H}$ (figs. 24, 25, 26) which I think represent two aspects of the same god, whom I identify as Kukulcan (cf. Kelley, 1962, p. 29, following Seler for the identification of $\operatorname{god} \mathrm{P}$ and Knorozov for the identification of $\operatorname{god} \mathrm{H}$ ).

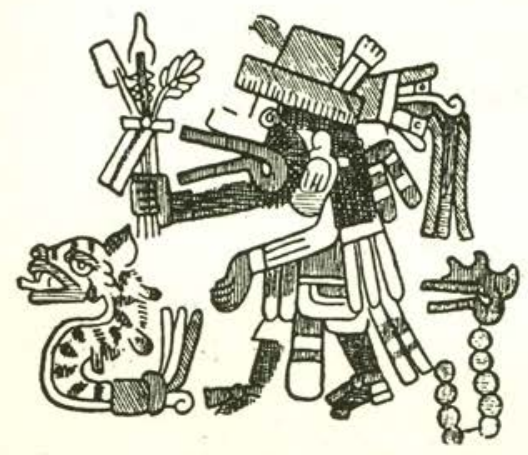

Fig. 37. Vienna. Nine Wind, dressed as wind god, with Feathered Canine Snake as name.

I think that this material warrants me in saying that the apparent probability of a Maya temple dedicated to Quetzalcoatl in the mid-Classic is substantially higher than would have been thought ten years ago. We can now reasonably infer that the Quetzalcoatl cult was present in Classic Teotihuacán times, we date that period earlier relative to the Mayas, and we know that there are clear-cut indication of strong Teotihuacán influence at Tikal well before 9.4.0.0.0. The Cotzumahualpan and Xochicalcan evidence shows a wide geographic spread of the cult, with the probable equivalent calendar name, at a time we would now regard as late Classic. The later but fuller evidence of the Borgia group and the Mixtecs helps us to see a unified picture.

In the light of this evidence, it seems worthwhile to point out that the exterior frieze of the Temple of the Cross shows a deity with cross-bands in his eyes, apparently the same as the front head of the 'two-headed dragon', also known as the 'Venus monster' (figs. 44, 46, 48). This figure is extremely 


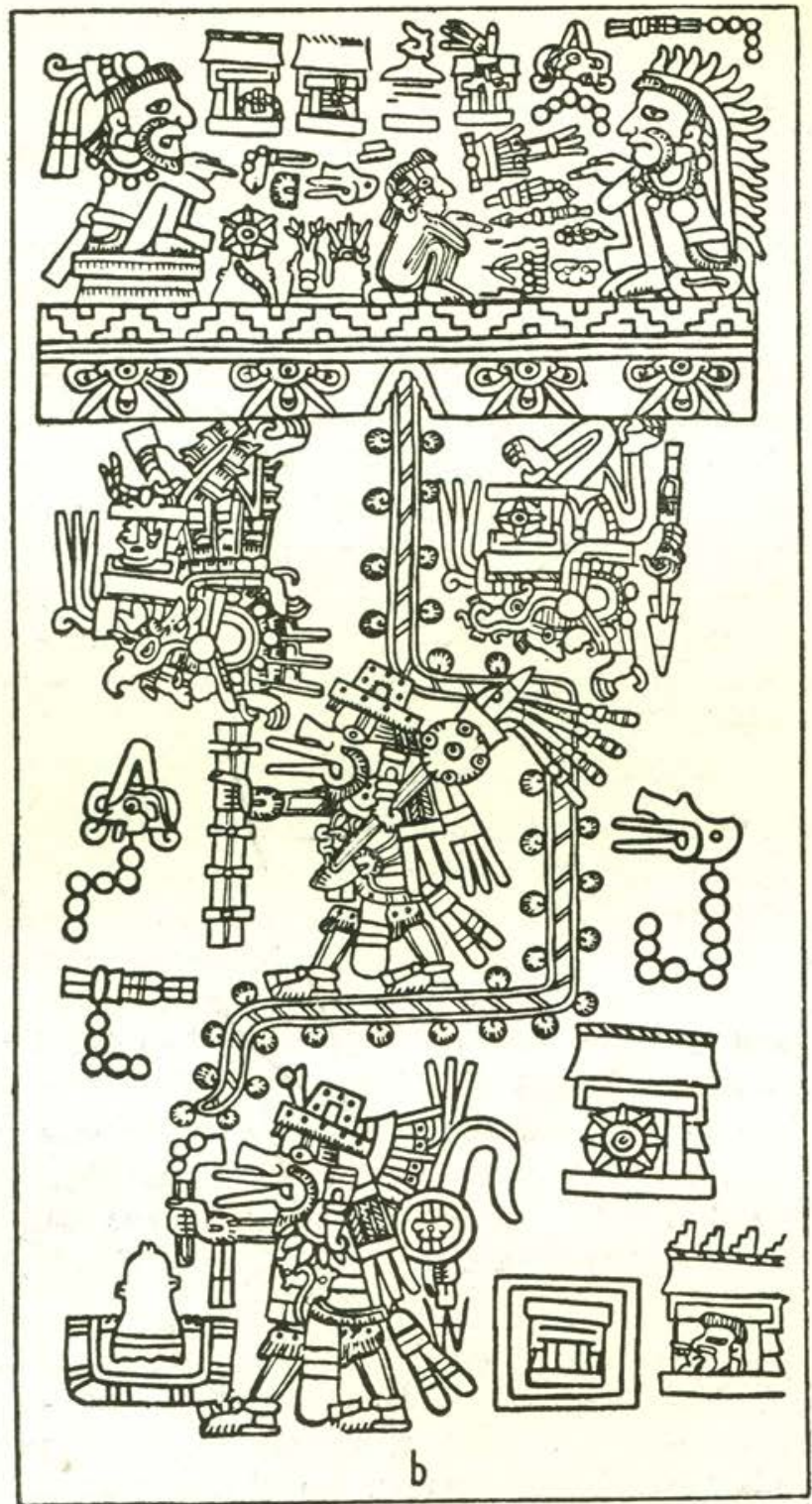

FIG. 38. Vienna. Nine Wind, dressed as wind god and carrying Venus staff, descends from heaven. 
similar to that from Tula recently identified by Saenz (1964, p. 71) as Tlahuizcalpantecuhtli, or Quetzalcoatl in his aspect of morning star (fig. 47) and to one from Chichén Itzá long ago identified by Seler (1902, I, p. 692) as Quetzalcoatl (fig. 45).

In sum we may say that the iconography of the tablet of the Temple of the Cross shows an emphasis on serpents, that several dates 9 Wind appear, and that one of these seems to refer clearly to the birth of a person or deity whose name includes the word 'serpent'. The external evidence of the Temple of the Cross seems to show a "Venus monster." Comparative evidence indicates the association of this constellation of traits with Nine Wind Quetzalcoatl. The prophecies for Katun 4 Ahau, in which the date $9 \mathrm{Ik} 15$ Ceh falls, refer to the coming of Kukulcan, the equivalent of Quetzalcoatl. It seems possible but far from certain that several related deities are referred to here. Berlin's GI god may refer either to a related deity, or to a special aspect of the Feathered Serpent deity.

I am, therefore, led to conclude that Berlin's GII refers to One Flower as maize god and probably also as sun god, his GIII to Thirteen Death as war god, and his GI probably to Nine Wind, a prototype of Kukulcan. It should be emphasized that, although I think these calendar names refer to major deities who are historically and functionally related to those with equivalent calendar names in other cultures or at other times, I am by no means certain as to the precise way in which their glyphs are to be read. I certainly do not think GI was actually read as Kukulcan, and doubt that GII was read Tzacab, although Tzac might be a possibility. Equally clearly, GIII is not to be read Ek Ahau or Vuc Ek Ahau.

A final point may be worth making, although the evidence is weak. I would suggest that the figures held in the hands of the human attendants may, in some fashion, represent the infant gods themselves. However, the characteristics of these figures certainly do not seem to be identical with those of the deities I have postulated for the three temples. Also, the presence of two "infant gods" in the Temple of the Foliated Cross is puzzling; I would rather have expected two figures in the Temple of the Cross, as Quetzalcoatl is said to have had a twin deity. 


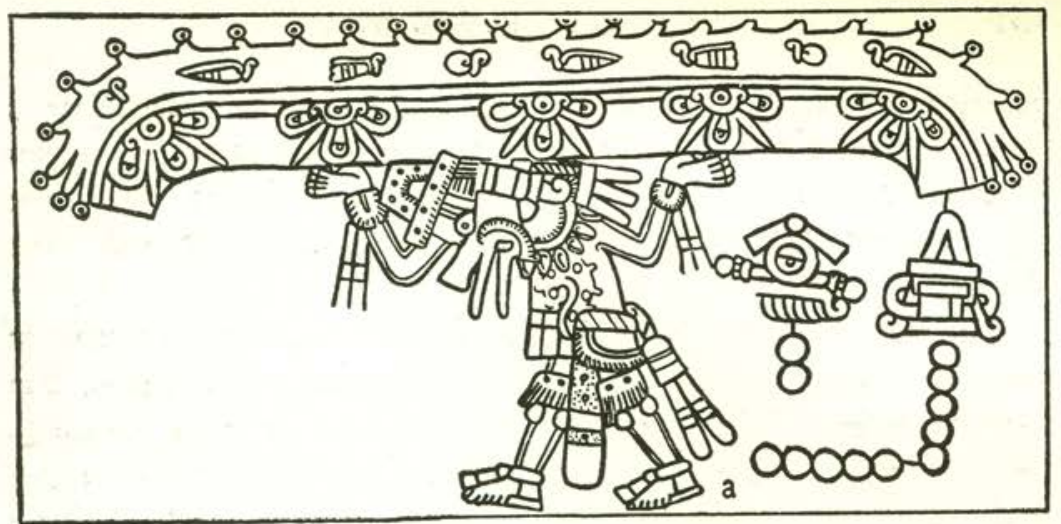

Fig. 39. Vienna. Nine Wind supports the starry heaven and the water above it. Note shell necklace and shell pectoral.

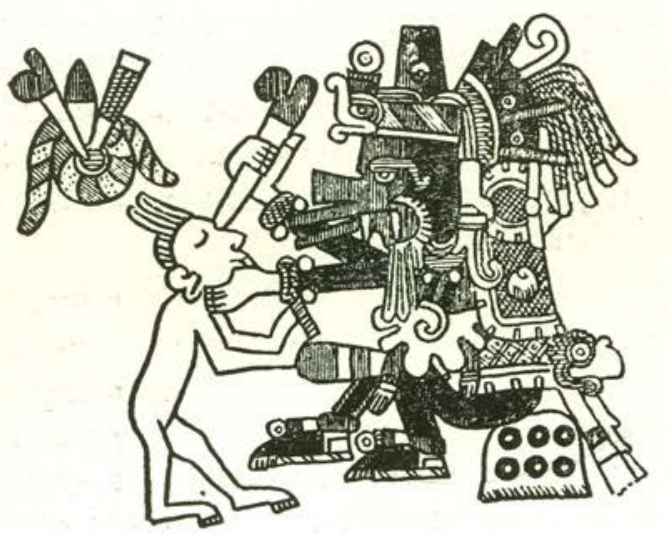

FIG. 40. Borgia. Bearded Quetzalcoatl with wind god mask, quetzal on back, shell pectoral.

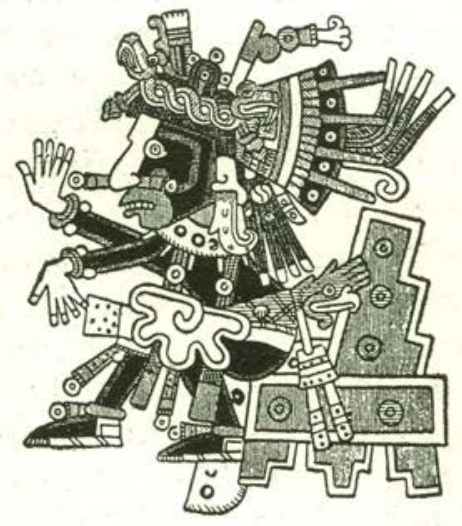

FIG. 41. Borgia. Quetzalcoatl with shell pectoral, quetzal on back, intertwined snakes in headdress, star on headdress.

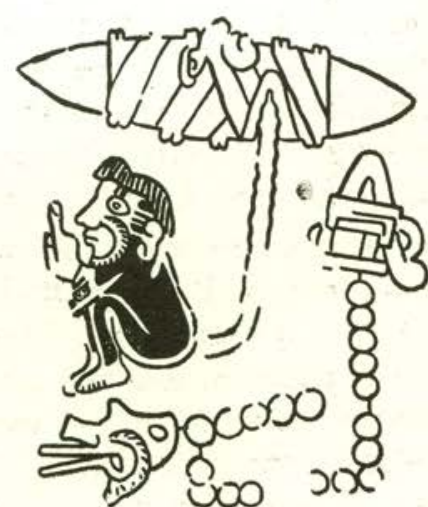

Fic. 42. Vienne. Supernatural birth of bearded deity from a flint knife, day 9 Wind, year 10 house. 
Berlin's interesting analysis of the reference to these gods in the Temple of the Inscriptions may be substantially supported by certain additional data which make it clear that ritual behavior is involved and that this is associated with some sort of cycles or periods. For the ritual association, his 'glyph $d$ ' contains first the yax glyph and then the glyph group for 'fire'. Yax here is certainly to be translated 'new'. This is the only reference to 'new fire' known to me in the inscriptions. In the second parallel phrase, the prefix to 'glyph $e$ ' is not clear but could be yax once more and 'glyph f' is 'sky', with an affix. In the third parallel phrase, Berlin's 'glyph $h$ ' once again has the yax, 'new' prefix. 'Glyph $i$, immediately preceding GIII (a war god according to my deductions) is, once again, 'fire' with affixes. While I do not know its meaning, I should point out that the non-variable elements of Berlin's 'glyph Z' are to be read phonetically as $\operatorname{tup}(a)$, according to phonetic readings which I consider well-established. Brinton (1895, p. 36) give tupul u uich kin or tupan $u$ uich kin, 'the eye of the day is covered over' or 'shut up' as terms for an eclipse of the sun. However, the correct root for these terms is apparently tupp, not tup.

The series of glyphs $\mathrm{X} 1, \mathrm{X} 2$ and $\mathrm{X} 3$ are probably, as Berlin suggests, deity names. Berlin mentions, but does not stress, that the elements of Xl (fig. 50) appear as the headdress of the deity whose head is the base of the tree in the Temple of the Cross (figs. 49, 51). This head is, as was first pointed out by Maudslay (1889-1902, 4, P1 92, 93) the rear head of the two-headed dragon (fig. 48). Spinden (1913, p. $66)$ pointed out that the $X I$ glyph group apparently refers to this deity. Thus Xl, like the accompanying $\mathrm{Gl}$, can safely be associated with a deity and with the Temple of the Cross. X2 has a 'smoke' prefix and closely resembles the so-called 'Venus monster', patron of the month Yax and identical with the front head of the two-headed dragon. In the latter, however, the crossed bands are normally in the eye rather than on the forehead. 'Glyph $a$ '. which follows X2, is, I suspect, merely an additional name or title of the deity which may be added or omitted without substantially changing the meaning. By analogy with $\mathrm{X} 1$, we might expect reference to the deity with a kan-cross on his forehead at the base of the tree in the Temple 


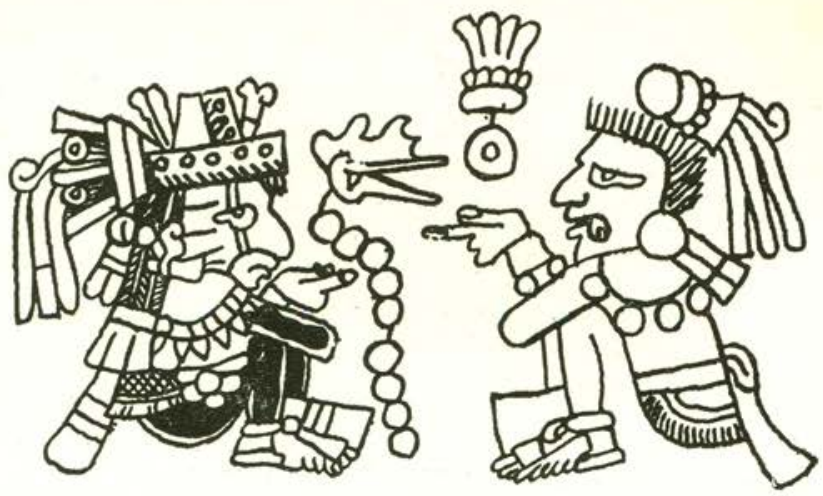

FIG. 43. Vienna. Nine Wind confers with One Flower about the marriage of his grandson (?), Five Wind, to One Flower's daughter, Nine Crocodile.

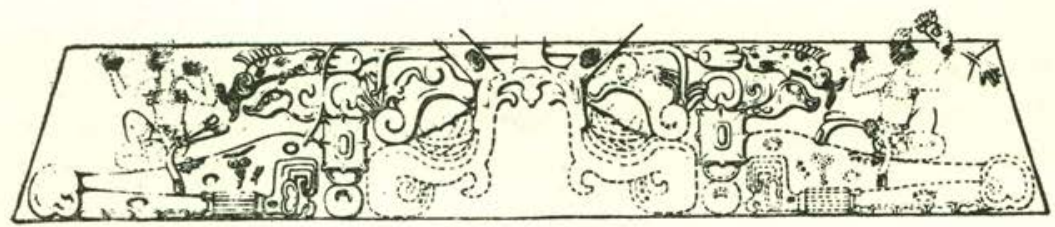

FIG. 44. Venus monster from external decoration of Temple of the Cross, Palenque.

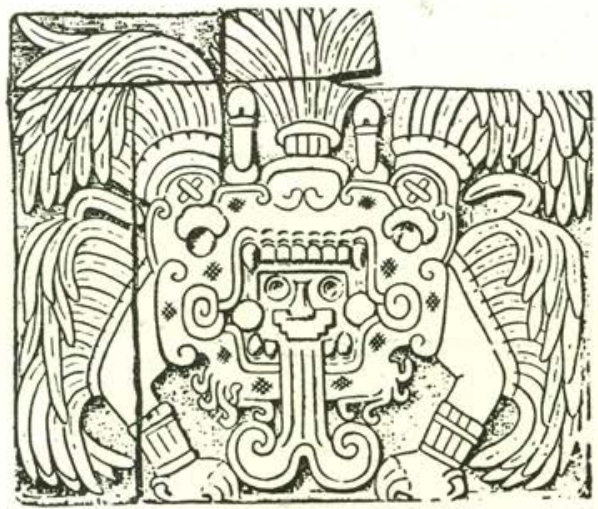

FIG. 45. Chichen Itza. Representation of Quetzalcoatl according to Seler. Note crossed bands above eye. 


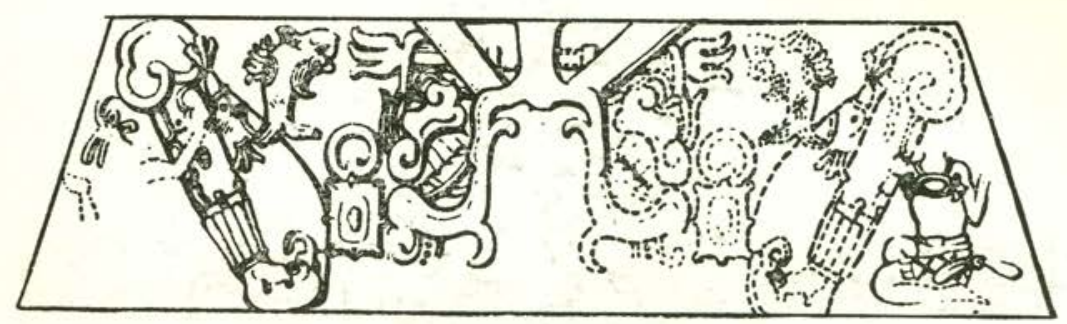

F!c. 46. Venus monster from external decoration, Temple of the Cross, Palenque. Note crossed bands in eye.

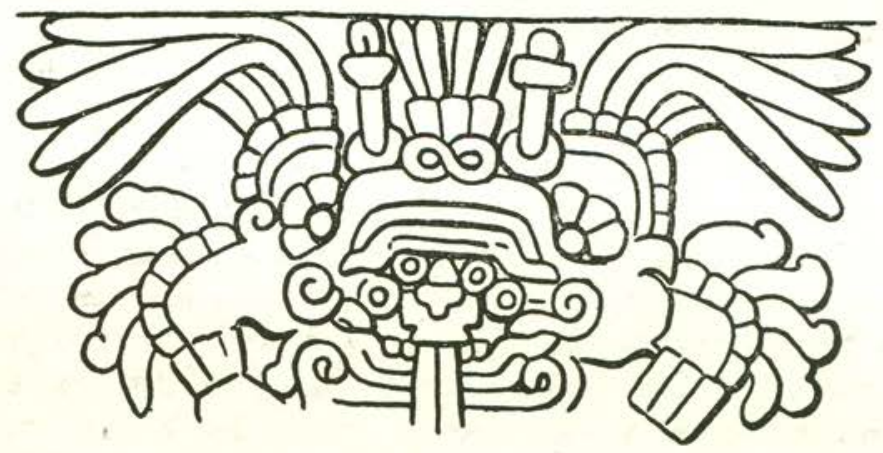

Fig, 47. Tula. Representation of Tlahuiscalpantecuhtli, i.e. of Quetzalcoatl as morning star, according to Saenz.

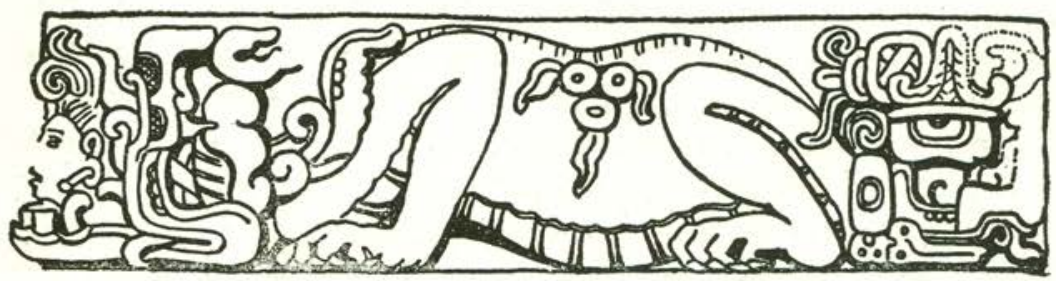

Fig. 48. Copan. The two-headed dragon. The Venus monster as front head, with crossed bands in eye. 


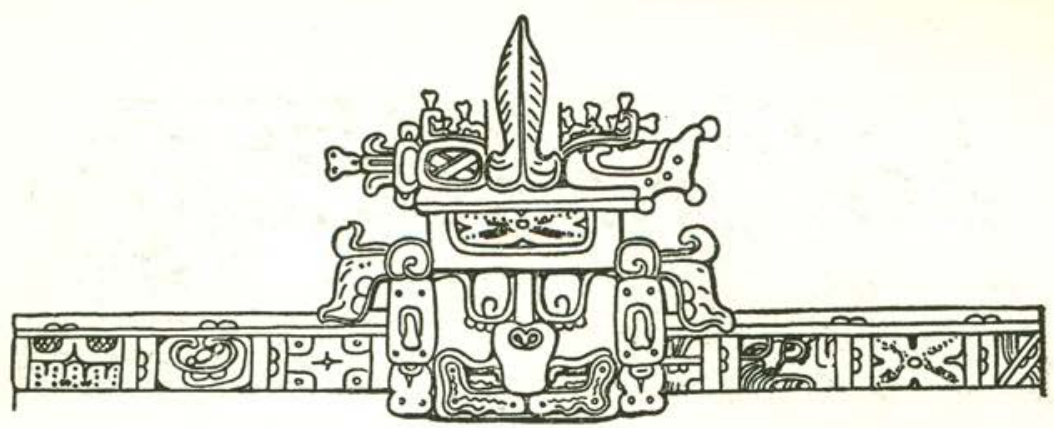

FIG. 49. Temple of the Foliated Cross, Palenque. Front view of rear head of twoheaded dragon.

of the Foliated Cross, but this is certainly not demonstrable by any means known to me.

'Glyph X3' is composed of a deity head and a constant suffix (T1030o:23). For this combination, we have a substantial number of references from Palenque and other sites which tend to support the view that this is a deity name. In the same inscription, X3 appears at J2, following the 9-16-9 clause and a verb. Here, X3 has the prefix 'white', as it does on the West panel at S9. X3 also appears with the prefix 'white' on Lintel 2 of Temple IV of Tikal, at B14, and three glyph blocks earlier at Al3 with the prefix 'black'. Here it immediately follows kinil balam in B12. I would be inclined to think that kinil is, here, either 'priest' or 'feast', and that X3 may be the deity connected with the priest or feast. The 'black' prefix likewise appears with X3 at C6a of Stela C at Copan. X.3 is also found with undeciphered affixes and a 'yellow' prefix at B2 on Stela H, Copan, and at C.3b, Copan, Stela A (referring to the same date). Even without searching for other examples, this strongly suggests that X3 is a deity name among those groups of gods who are assigned to different directions, represented by different colors.

'Glyph C' is probably to be read 'hun kal x', here 'one count' (plus grammatical affix) and the associated 'glyph D' contains as its main feature the grouping which is usually read 'baktun' and which I read cuc, cycle. In the second series, these have a prefix which is identical to the prefix to $\mathrm{X} 1$, save that the latter does not have a row of dots found in D. This 
Fic. 50. Glyph X-1 of Berlin, identified by Spinden as glyphs for the rear head of the two-headed dragon, from the Temple of the Inscriptions, Palenque.
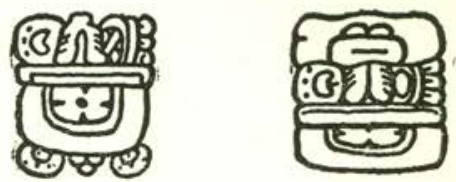

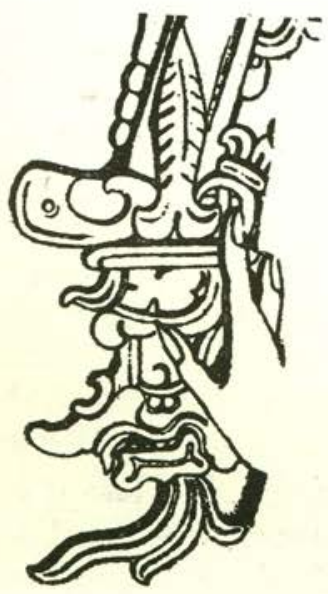

Fig. 51. Another view of the rear head of the two-headed dragon. Note element like a leaf or feather.

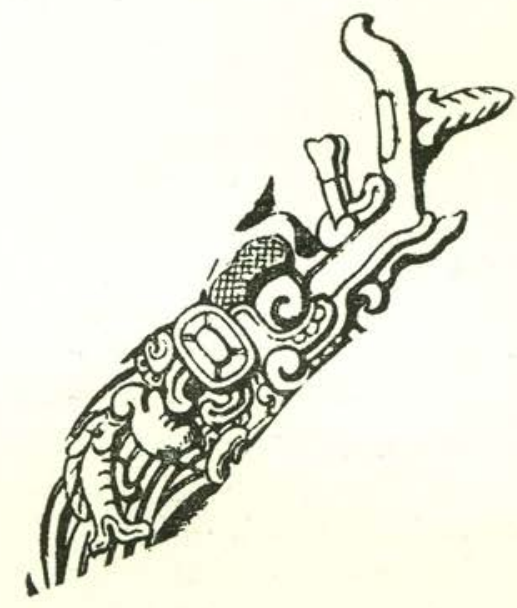

Fic. 52. Probable Chicchan snake, with very extended upper jaw, containing 'feather' element as an apparent tooth, from headdress of deity outside the sanctuary, Temple of the Cross. Cf, figs. 23, 53.

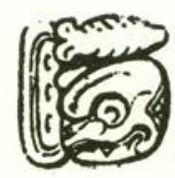

Fig. 53. T 11.212:764 x -'feather'?? - snake Personal name, associated with date 9 Wind. 
prefix sufficiently resembles the prefix of the 'pictun' glyph group to have been included among them by Thompson (1950, fig. $\left.26, n^{\circ} 11\right)$, I think mistakenly. At any rate, I would expect these glyphs to be associated with recurring cycles of some sort.

It seems to me fairly clear that the first series belongs to 9.11.0.0.0, 12 Ahau $8 \mathrm{Ceh}$ and that the second series relates to 9.12.0.0.0, 10 Ahau 8 Yaxkin. Although I think that there is a significant amount of information on possible similar cycles at other sites, associated with these dates, and generally supporting Berlin's views, the evidence is too diffuse for inclusion here.

In short, I have tried to show that the Temple of the Cross was dedicated to $\mathrm{Kuk}(\mathrm{ul})$ can under the calendar name Nine Wind, that the Temple of the Foliated Cros was dedicated to (Ah Bolon?) Tzacab, both as an agricultural deity and, possibly, as a sun deity, under the name One Flower, and that the Temple of the Sun was dedicated to Ek Ahau, the war god, under the calendar name Thirteen Death. The evidence on which these conclusions are based is summarized and compared in Table I. The conclusion that the war god was an important figure among the mid-Classic Maya is a marked change from the emphasis on the peacefulness of the Mayas which has long been prevalent. However, I think the iconography of the "Temple of the Sun" is adequate to prove this, even if my central thesis should ultimately be rejected. The even more startling deduction that the 'Mexican' Quetzalcoatl/Kukulcan has a clearcut prototype in the central deity of the Temple of the Cross must ultimately depend upon the thesis that the leading dates are the birth-days of the gods.

I wish to thank Tatiana Proskouriakoff and Heinrich Berlin for helpful comments; Sr. Jorge Ruz for preparing the drawing of Fig. 36, and the Milwaukee Public Museum for supplying, through Dr. Lee Parsons, the photographs from which the drawing was made. 


\section{BIBLIOGRAPHY}

Anders, Ferdinand: Das Pantheon der Maya. Graz, Austria, 1963.

Barrera Vásquez, Alfredo and Silvia Rendón: El libro de los libros de Chilam Balam. México, 1948.

BerLin, Heinrich: "Glifos nominales en el sarcófago de Palenque", Humanidades 2, $\mathrm{n}^{\circ}$ 10, pp. 1-8. Guatemala, 1959.

- "The Palenque Triad", Journal de la Société des Américanistes, n.s. 52, pp. 91-99. París, 1963.

Bowditch, Charles P.: Maya Numeration, Calendar and Astronomy. Cambridge, 1910.

Brinton, Daniel G.: A Primer of Mayan Hieroglyphics. Philadelphia, 1895.

Burland, Cottie A.: "The Inscription on Stela I, El Castillo, region of Santa Lucia Cotzumahualpa, Guatemala", 32nd International Congress of Americanists. Copenhagen, 1958.

Caso, Alfonso: "Glifos teotihuacanos", Revista Mexicana de Estudios Antropológicos 15, pp. 57-70. México, 1959.

- "Nombres calendáricos de los dioses", El México antiguo 9, pp. 77. 100. México, 1961.

Dresden Maya Codex, editions by Gates, 1932; Villacorta and Villacorta, 1930; Evreinov et al., 1961; and others.

Evreinov, E. V., Y. G. Kosarev, and V. A. Ustinov: Primenenie Elekytronnikh Vichislitelnikh Mashin $v$ Issledovanii Pismennosti Drevnikh Maya, 3 vols. Novosibirsk, 1961.

Gates, William: The Dresden Codex. Baltimore, 1932.

Genet, Jean: "Les glyphes symboliques dans l'écriture maya-quichée. Le glyphe symbolique de la guerre", Revue des Études MayasQuichées, 1, pp. 23-32. París, 1934.

HaEkel, Josef: "Zur Problematik des obersten goettlichen Paares im alten Mexiko", El México Antiguo 9, pp. 39-76. México, 1959.

Kelley, David H.: "Glyphic evidence for a dynastic sequence at Quirigua, Guatemala", American Antiquity 27, pp. 323-35. Salt Lake City, 1962.

- "A history of the decipherment of Maya script", Anthropological Linguistics 4, $\mathrm{n}^{\circ}$ 8, pp. 1-48. Bloomington, Indiana, 1962.

KING, Edward (Lord Kingsborough) : Antiquities of Mexico 2. London, 1831. 
LANDA, cf. Tozzer.

Long, Richard C. E.: "The Zouche Codex", Journal of the Royal Anthropological Institute, 56, pp. 239-258. London, 1926.

Madrid Maya Codex, edition by Villacorta and Villacorta. Guatemala, 1930.

Maudslay, Alfred P.: Archaeology: Biologia Centrali-americana. London, 1889-1902.

Morley, Sylvanus G.: The Ancient Maya. Stanford, Calif., 3rd printing, 1947.

Noriega, Raúl, Carmen Cook de Leonard and Julio Rodolfo Moctezuma: Esplendor del México Antiguo, 2 vols. México, 1959.

Parsons, Lee A.: The Middle American Co-Tradition Ms., Ph.D. Thesis. Harvard University. Harvard, 1964.

Popul Vuh cf. Recinos et al.

Proskouriakoff, Tatiana: "Historical implications of a pattern of dates at Piedras Negras, Guatemala", American Antiquity 25, pp. 454.475. Salt Lake City, 1960.

- "Historical Data in the Inscriptions of Yaxchilan", Estudios de Cultura Maya 3, pp. 149-167. México, 1963.

Recinos, Adrián, Delia Goetz and Sylvanus G. Morley: Popol Vuh. Norman, Oklahoma, 1950.

Roys, Ralph L.: The Book of Chilam Balam of Chumayel, Carnegie Institution of Washington. Washington, 1933.

Ruz Lhuillier, Alberto: "Exploraciones arqueológicas en Palenque: 1953", Anales, INAH, 10, pp. 69-116. México, 1958.

Sáenz, César A.: "Las estelas de Xochicalco", 35th International Congress of Americanists, 2, pp. 69-84. México, 1964.

SAHAGún, Bernardino de: "Relación breve de las fiestas de los dioses", Tlalocan 2, n 4, pp. 289-320. México, 1948.

Schellhas, Paul: "Representation of Deities of the Maya Manuscripts", Papers, 4, n 1, Peabody Museum of Harvard. Cambridge, Mass., 1904.

SÉJOURNÉ, Laurette: Burning Water. New York, 1960.

- El Universo de Quetzalcóatl. México, 1962.

SELER, Eduard: Gesammelte abhandlungen zur amerikanischen Sprachund Alterthumskunde. Berlín, 1902-23.

- "Venus period in the picture writings of the Borgian Codex group", BAE, Bulletin 28, pp. 355-391. Washington, 1904. 
- The Tonalamatl of the Aubin Collection. Berlin and London, 1900-1.

- Die Alten Ansiedelungen von Chacula. Berlín, 1901.

- Codex Féjérvary-Mayer. Berlin and London. 1901-2.

- Codex Vaticanus 3773. Berlin and London, 1902-33.

- Codex Borgia 2. Berlín, 1906.

Spinden, Herbert J.: A Study of Maya Art, Peabody Museum, Memoir 6. Cambridge, Mass., 1913.

- "Diffusion of Maya Astronomy", The Maya and their Neighbors. New York, 1940.

Teeple, John E.: "Maya Astronomy", Contributions to American Arch. aeology 1, $\mathrm{n}^{\circ}$ 2, pp. 29-116, Carnegie Institution of Washington. Washington, 1930.

Tномpson, J. Eric: "Sky bearers, colors, and directions in Maya and Mexican religion", Publication 346, Carnegie Institution of Washington. Washington, 1934.

- Maya Hieroglyphic Writing: Introduction, Publication 589, Carnegie Institution of Washington. Washington, 1950.

- A Catalog of Maya Hieroglyphs, Norman. Oklahoma, 1962.

Tozzer, Alfred M.: Landa's Relación de las cosas de Yucatán, Peabody Museum Papers, 18. Cambridge, Mass., 1941.

- Chichen Itza and its Cenote of Sacrifice, Peabody Museum, Memoirs 11, 12. Cambridge, Mass., 1957.

Vienna Mixtec Codex, in King, 2. 1931.

Villacorta, J. Antonio and Carlos A. Villacorta: Códices Mayas. Guatemala, 1930.

Zimmerman, Günter: Die Hieroglyphen der Maya-Handschriften. Hamburg, 1956. 


\section{THE BIRTH OF THE GODS AT PALENQUE}

Figures

1

2

3

4

5

6

7

8

\section{Sources of figures}

Maudslay, 1889-1902, 4, Pl. 81

Maudslay, 1889-1902, 4, Pl. 75

Maudslay, 1889-1902, 4, Pl. 82

Seler, 1902-23, 3, p. 673

Morley, 1947, Pl. 29

Maudslay, 1889-1902, 4, Pl. 88

Dresden, p. 14c, ed. Gates, 1932

Maudslay, 1889-1902, 4, Pl. 72

Maudslay, 1889-1902, 4, Pl. 88

Seler, 1902-23, 3, p. 253

Dresden, p. 74, Evreinov, Kosarev and Ustinov, 1961

Madrid, p. 32a, Thompson, 1950, fig. 13

Madrid, p. 33b, Thompson, 1950, fig. 13

Maudslay, 1889-1902, 4, Pl. 61

Maudslay, 1889-1902, 4, Pl. 61

Thompson, 1950, fig. 22, nos. 8-9

Thompson, 1950, fig. 24, nos. 38, 41

Morley, 1947, Pl. 29

Noriega, Cook de Leonard, and Moctezuma, 1959, 2, p. 925

Noriega, Cook de Leonard, and Moctezuma, 1959, 2, p. 925

Maudslay, 1889-1902, 4, Pl. 88

Noriega, Cook de Leonard, and Moctezuma, 1959, 1, p. 172

Maudslay, 1889-1902, 4, Pl. 81

Maudslay, 1889-1902, 4, Pl. 61

Maudslay, 1889-1902, 4, Pl. 75

Madrid 26a, b, Villacorta and Villacorta, 1930

Dresden 4a, Seler, 1902-23, 1, p. 696

Seler, 1902-23, 1, p. 697

Seler, 1902-23, 1, p. 697

Dresden glyph from Seler, 1.c., rest from Bowditch, 1910, Pl. 16

Bowditch, 1930, Pl. 16

Spinden, 1913, fig. 52

Séjourné, 1960, fig. 52

Séjourné, 1960, fig. 53

Séjourné, 1960, fig. 55

Séjourné, 1962, fig. 38

Caso, 1959, fig. 15

Ruz, Jorge, and the Milwaukee Public Museum photos

Vienna, p. 33, Seler, 1906, 1, p. 581

Vienna, p 48, Spinden, 1940, fig. 6 


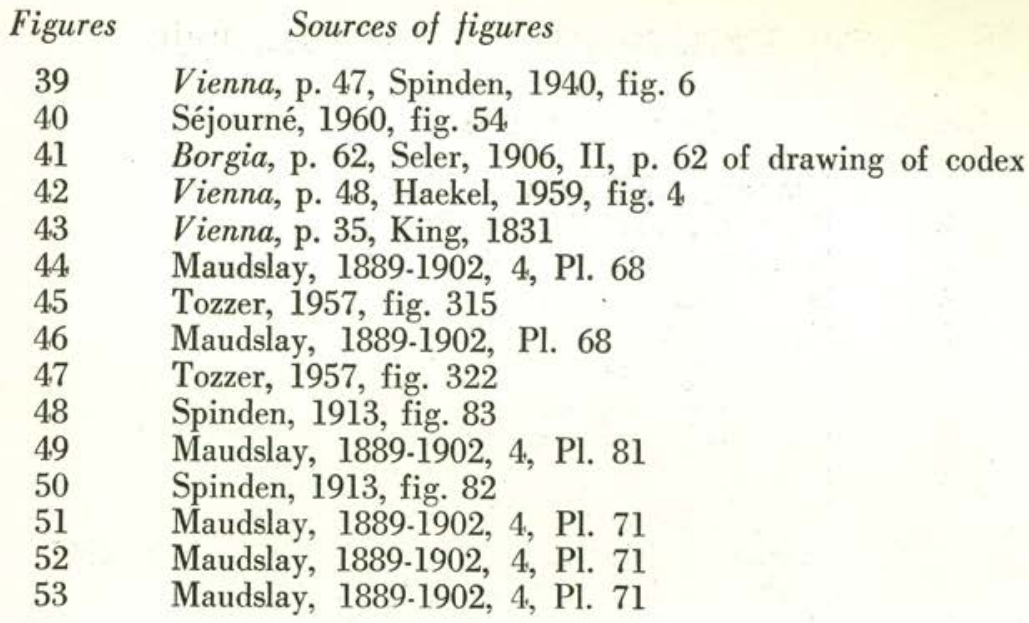




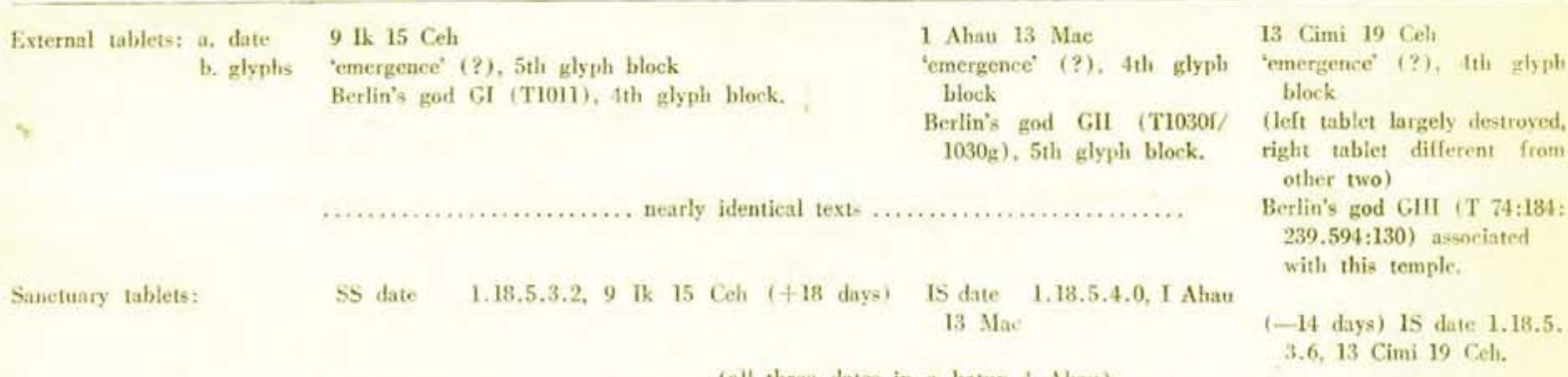

Correspouting caleudar name of deity:

Documcatary and icono graplac information:

Prophecy for Katum 4 Ahau:

Interior iconography:

Exterior iconograply: Glyphic context:

\section{Nine iVind}

Azlee: Quetzalcoatl (Featliered Serpent) born on 9 Wind. Itentified with Tluluizcalpantecuhtli. a Venus god; with Ehecatl, a wind god; and with a bearded human ruler with a shell symbol. Twin of Xolotl.

Mixtec and Borgia group: Nine Wind, Yenus nod and wind god, bearded, shell symbol, shell neck. lace, dyanstie ancestor, twin.

Xochicalco: Nine Reptile Eye, Feathered Serpent, ruler.

Cotzumahualpan: Nine Reptile Eye, posvible Venus \#nd.

Kukulean (Feathered Serpent) will come.

The quetzal will be in the hoben 5 Ben, 5 Reed)

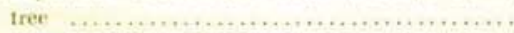

The morning -tar will appear.

A quetzal with a deity liead perehed in a stylized serpent tree.

To right: ha-?-ben, ho-? te and tall priest.

To left: ho-?.etz'nab, ho(?)-tu-kol and short individual.

Two reptilian heads decorate tree.

Yax symbol prominent.

Rear heal of two-headed dragon at foot of tree.

Planetary or celestial symbols at base.

The Venus monster (like Tiahnizcalpastecuhti) IS: 8 Ahau 18 Zee S8: 9 Ik 15 Ceh (F.1, F1) to: I Ahan 18 Zots (A16,

B16)

"God K" passage, "xouti"

(A15)

'birtl' (A17) earth god. 'emergence' (1:2) and re.

dess (B17) ferences to a zodthes ? Ik O Zac (E9, F9)

'birth' (C17) 'emergence' 9 Ik (F12), birth' (E13) (D17)

$$
\begin{aligned}
& \text { ??. '-nake' (E13) } \\
& \text { ??. (goddess) (E14) } \\
& \text { ?. cmergence' (?) } \\
& \text { F11b) }
\end{aligned}
$$

(several intervening passages and forward to:

$$
2 \text { Cib } 14 \text { Moll }
$$

\section{One Flower}

Axtec: Centeotl, the Maize god, born on 1 Flower in Tumo. anchan (overlaps in funs: tions and iconography with Xochipilli, Flower Prince, who has sun uod affilia. tioas).

Mixtes: One Flower, a sun god.

Quiche: brothers One Flowet and Seven Flower, one be. came the sun. one became the moon.

Maya: One Flower, lond of the underworld, possible Venus god.

Possible functional equation of Centeotl with Ah Bolon Tracab/Ged K.

or .... The quetzal will be in the kaxte liff. lanxte, harvest tree).

A quetzal with a deity head perched in a stylized maize tree.

To left: ho-?-luen, ho-?te (tree) and all priest (?).

To right: ho-?-etz'nab, ho-tu. kal, and short individual.

Representation of the maize god and a variant of god $K$ decorate tree. Stylized One (?) Flower above head of maize god.

Head of nod with lan-eross at foot of tree.

On left, a water (?) god; on right, it different variant of God $\mathrm{K}$ and the maize god emerge from a large shell; lower glyph block on shell is postulated 'emergence.'

is: 1 Aham 13 Mec

Io: 1 Canac 7 Yax (B13 A14)

"God K" pasage, 'weet" (B15) birtli (B16) .... GII (C2, D2)

count from I that (from). 'birth"

(C5) CII (D5, C6), emersence' (D6) 'fi-h-in-land' tite (C9) of goddess? (C10, D10) 'energence' (C11)

forward to:

$2 \mathrm{Cib}$ it $\mathrm{Mol}$
Thirteen Death

Tzendal: Oxlahun toj (Thir. teen Death) identical with Yeal Alaa (Black Lord), a war god, chief of seven black gods. Dresden: God L, a black pod, probably of war.

Madrid: God Z, probablv equals God L.

Sudden death - vomit of blood' will eome.

Shield and spears (war).

Face of a jaguar god on the shield.

Seven-black-?, by shield, above God L, on left. Nine-?-?, by shield, above another (?) black god with jaguar traik.

Earth symbols at base with up-turned deity head alter nating.

IS: 13 Cimi 19 Ceh

to: (9 Manik?) $10 \mathrm{Zwe}$

"Find $\mathrm{K} "$ passage, 'north' (A15)

'blood-letting' (B16)

'birth' (C1) .... GIII (D6)

(headless jaguar. D2, 'fire' C5)

birth' (C10) 'emergence?

(1)10)

blood-letting rite (D11) of goddess ? ( $\mathrm{C1} 2, \mathrm{D} 12, \mathrm{Cl} 3)$ (same goddess as TFC)

forward to:

2 Cib $14 \mathrm{Mol}$ 